Article

\title{
The Sustainable Approach to Corporate Social Responsibility: A Global Analysis and Future Trends
}

\author{
Emilio Abad-Segura ${ }^{1}\left(\mathbb{D}\right.$, Francisco Joaquín Cortés-García ${ }^{2}$ and Luis J. Belmonte-Ureña ${ }^{1, *(\mathbb{C}}$ \\ 1 Department of Economy and Business. University of Almería, 04120 Almería, Spain; eas297@ual.es \\ 2 Faculty of Business and Management, Universidad Autónoma de Chile, 7500912 Santiago, Chile; \\ franciscojoaquincortesgarcia@gmail.com \\ * Correspondence: lbelmont@ual.es
}

Received: 2 September 2019; Accepted: 26 September 2019; Published: 28 September 2019

\begin{abstract}
Due to the process of globalization, companies are obligated to observe corporate social responsibility and best practices from a sustainability approach towards their stakeholders and society. The explicit aim is to determine the relevance of the corporate social responsibility (CSR) and its relationship with sustainability, in order to establish trends and future lines of research. The evolution of global research on this subject has been studied from 2001 to 2018. For this purpose, a bibliometric analysis of 1832 articles has been applied, obtaining results of the scientific productivity of the journals, authors, institutions, and countries that contribute to this research. Evidence shows a growing interest in studying the relationship between socially responsible practices and the dimension of sustainability. The main category is Business, Management, and Accounting. The most productive journals are the Journal of Business Ethics and Sustainability. The authors with the most articles are García-Sánchez, Moneva, and Moratis, while Kolk is the most cited. The most prolific institution is the University of Salamanca. The United States is the country with the most publications and quotes. France and China are the countries with the largest number of international collaborations in their work. Global research has been on an upward trend with optimal publication rates in recent years.
\end{abstract}

Keywords: corporate social responsibility; sustainability; bibliometric analysis; scientific research

\section{Introduction}

The importance of good corporate social responsibility (CSR) practices that are focused on sustainability is increasingly relevant. Through the CSR, an organization acquires a commitment to society and stakeholders to contribute to sustainable development and social welfare, applying both local and international regulations, as well as maintaining ethical behavior and providing transparent management. The role of sustainability in the CSR is widely documented in the scientific literature [1,2].

This study reveals that, in addition to the globalization process, it is crucial for organizations to link CSR with sustainability. This makes the corporate impact positive by contributing to economic and social development as well as environmental factors [3].

Although the concept of the CSR has undergone no significant changes since its initial definition, its role in company strategy $[4,5]$ has evolved along with the effect of socially responsible actions on sustainable development [6,7].

The implementation of CSR includes measurements of social commitment and sustainability. They are applied to internationally recognized factors, including parameters from Sustainable Development Goals SDGs and indicators such as Global Reporting Initiative (GRI), Sustainability Accounting Standards Board (SASB) and International Integrated Reporting (IIRC) [8-10]. 
In this sense, sustainability has been affecting CSR, especially with the publication of the SDBs. From this point of view, best practices developed on the subject of sustainability by organizations need to be aligned with SDG benchmarks [11] in order to evaluate and obtain information on CSR actions.

Likewise, in order to improve environmental standards in companies, the European Commission proposes a regulatory framework to promote CSR and sustainability in relation to EU and national activities. In this regard, CSR policies and initiatives are highlighted, such as the EU policy on sustainable development, world trade and sustainable development, international partners, sustainable development criteria and CSR in each of the trade agreements, impact assessments and sustainability of trade agreements [12-14]. For its part, ISO 26,000 creates a global guide for public and private sector organizations, based on an international consensus, for the application of best practices in CSR and promoting business sustainability [15].

The purpose of this review of the research was to examine the evolution of scientific knowledge based on the relationship between corporate social responsibility and sustainability. With this general review of the relationship between sustainability and CSR activities, a critical analysis is provided of the research of future lines in this field. The work also presents an approach that clarifies to future research what the link is between CSR's sustainability actions with the aim of increasing the understanding of underlying effects and the conditions that determine certain specific results. Despite the extensive literature in this field of research, no bibliometric reviews on the relationship between CSR and sustainability have been found in the literature review conducted.

Consequently, the main goal of this study is to analyze research trends on corporate social responsibility practices focused on overall sustainability during the period between 2001-2018. Thereby, the explicit aim is to determine the relevance of the CSR and its relationship with sustainability, in order to establish trends and future lines of research.

To get answers to the research questions, a sample of 1832 articles from selected scientific journals from the Scopus database has been analyzed. This review uses the bibliometric method to synthesize the knowledge base on the sustainable approach to corporate social responsibility. The results showed the contributions of this line of research, which has identified the main drivers, their future trends, and revealed certain gaps of critical knowledge. It can be concluded that CSR, despite being an accounting term, is becoming less financial and more global, sustainable and environmentally friendly.

\section{Literature Review and Background}

In 1953, Howard R. Bowen exposed the relationship between companies and society in his work Social Responsibilities of the Businessman [16]. It laid out the foundation of CSR by stating that "the obligations of businessmen to pursue those policies, to make those decisions, or to follow those lines of action which are desirable in terms of the objectives and values of our society".

In 1991, Archie B. Carroll integrated the economic, legal, ethical and philanthropic responsibilities of companies in the publication The Pyramid of Corporate Social Responsibility: Towards the Moral Management of Organizational Stakeholders. Stated here is that the CSR could only be implemented if managers take a moral approach in the development of their activity [17].

Thus, the CSR emerged as a response from large companies to a growing social and corporate concern with the intention of addressing certain issues, which included social, environmental and consumer interests $[4,16]$. As for the business structure, CSR departments are usually included in the communications, marketing relations, or corporate foundations department.

The concept of sustainability first formally appeared in the Brundtland Report in 1987 [18]. It referred to meeting current needs, relative to development and the environment, without compromising the needs of future generations [19].

In 1998, another attempt was made to broaden the definition of sustainability when J. Elkington [20] presented the idea of sustainability as a triple bottom line. This referred to the necessity of including social and environmental aspects with the financial considerations of a company [21,22]. It was suggested that social responsibility, economic value and the environmental impact of a company [23-25] 
could work together. Here we can see that the CSR's sustainability approach involves social, environmental and economic variables. This triple approach has become more relevant in recent years. The United Nations drafted the 2030 Agenda for Sustainable Development in 2015. It included 17 Sustainable Development Goals (SDGs) and 169 indicators [26,27]. Some of these indicators measure the progress of actions in order to achieve sustainability regarding social, economic and environmental factors.

In the traditional economic system, there was an incompatibility between economic growth and ecological balance. This idea alludes to meeting current needs without damaging the capacity of future generations [28]. Thus, numerous interpretations of sustainable development agree that the policies and actions proposed to achieve economic growth must respect the environment and be socially equitable $[29,30]$.

There is a general awareness that a good portion of economic activities are not sustainable in the medium and long term. For example, manifestations such as climate change suggest that the economic model needs to be changed as a firm commitment to future generations. For this reason, the aim is to maintain economic growth while adjusting it to the limitations of nature as a renewable resource [31].

Due to the dynamic nature of the concept of sustainability, there is no tangible definition [32], so the researcher is the one responsible for giving a detailed description of its meaning [33,34].

Some authors believe the concept of CSR has achieved its development and can now be replaced by the idea of corporate sustainability $[35,36]$. This refers to a tool capable of providing information to the market and investors, which allows companies to know whether their activities are sustainable in the medium and long term [37]. The Dow Jones Sustainability Index offers its most accepted definition: "a business approach that seeks to create long-term value for shareholders by leveraging opportunities and effectively managing the risks inherent in economic, environmental and social development" [38].

Among the initiatives trying to achieve corporate sustainability, the organization must promote the development of a corporate strategy to improve business performance along with social and environmental impact [39]. It should also manage the opportunities, risks, and consequences of an integrated sustainability strategy. Finally, it should also incorporate dynamics that had not previously been considered in decision-making [40] and create strategic planning scenarios to interpret consumer attitudes or competitive sustainability decisions [41,42].

Table 1 presents the main results of the literature review or state of the art of the object of study of the research the relationship between corporate social responsibility and sustainability.

Table 1. Main literature reviewed of the object of research.

\begin{tabular}{|c|c|c|c|}
\hline Article Title & Author(s) & Year & Journal \\
\hline \multicolumn{4}{|l|}{ The pyramid of corporate social responsibility: } \\
\hline $\begin{array}{l}\text { Toward the moral management of } \\
\text { organizational stakeholders. [17] }\end{array}$ & Carroll, A.B. & 1991 & Business horizons \\
\hline $\begin{array}{c}\text { Review of sustainability terms and their } \\
\text { definitions. [32] }\end{array}$ & Glavič, P.; Lukman, R. & 2007 & $\begin{array}{l}\text { Journal of Cleaner } \\
\text { Production }\end{array}$ \\
\hline $\begin{array}{l}\text { The role of corporate social responsibility in } \\
\text { strong sustainability. [1] }\end{array}$ & $\begin{array}{l}\text { Málovics, G.; Csigéné, } \\
\text { N.N.; Kraus, S. }\end{array}$ & 2008 & $\begin{array}{l}\text { The Journal of } \\
\text { Socio-Economics }\end{array}$ \\
\hline $\begin{array}{c}\text { Triple bottom line and sustainability: A } \\
\text { literature review. [23] }\end{array}$ & Alhaddi, $\mathrm{H}$. & 2015 & $\begin{array}{l}\text { Business and } \\
\text { Management Studies }\end{array}$ \\
\hline $\begin{array}{c}\text { Corporate social responsibility and } \\
\text { sustainability balanced scorecard: The case } \\
\text { study of family-owned hotels. [43] }\end{array}$ & $\begin{array}{l}\text { Kang, J.S.; Chiang, C.F.; } \\
\text { Huangthanapan, K.; } \\
\text { Downing, S. }\end{array}$ & 2015 & $\begin{array}{l}\text { International Journal of } \\
\text { Hospitality Management }\end{array}$ \\
\hline $\begin{array}{l}\text { The social responsibility of international } \\
\text { business: From ethics and the environment to } \\
\text { CSR and sustainable development. [44] }\end{array}$ & Kolk, A. & 2016 & $\begin{array}{l}\text { Journal of World } \\
\text { Business }\end{array}$ \\
\hline $\begin{array}{l}\text { The corporate sustainability typology: } \\
\text { Analysing sustainability drivers and fostering } \\
\text { sustainability at enterprises. [42] }\end{array}$ & $\begin{array}{l}\text { Silvestre, W.J.; Antunes, } \\
\text { P.; Leal Filho, W. }\end{array}$ & 2018 & $\begin{array}{l}\text { Technological and } \\
\text { Economic Development } \\
\text { of Economy }\end{array}$ \\
\hline $\begin{array}{c}\text { Corporate sustainable development. Revisiting } \\
\text { the relationship between corporate social } \\
\text { responsibility dimensions. [10] }\end{array}$ & Ait Sidhoum, A.; Serra, T. & 2018 & $\begin{array}{l}\text { Sustainable } \\
\text { Development }\end{array}$ \\
\hline
\end{tabular}


The foundations of CSR's sustainable approach are underpinned by a small number of theories, so its insertion into organizations is properly substantiated. From the literature review related to the different theories consulted in this research, it established the framework of the impact of the environmental dimension on the social responsibility of the company.

Thus, the theoretical approach of stakeholders, outlined in 1984 by Freeman [45], was established. Previously, there was a need to disclose active contributions of corporate social responsibility [46,47]. The interest in CSR has increased along with progressive social demands for companies to take responsibility for their social impacts and to serve the general interest [48] and not just the minority of stockholders $[49,50]$. For this reason, many companies have changed their business models to reflect CSR concepts [51,52]. While these changes were initially intended to include environmental and social objectives, companies have also taken an interest in how they interact with stakeholders [53,54].

Milton Friedman stated in the shareholders' theory that a company's sole responsibility is to increase its profits [55]. This implies that sustainable optimal management can hardly be achieved if creating economic value for stakeholders is the only focus. This creates a skewed view of reality in the interactions between the company and its environment [56]. Consequently, the concept of value should be broadened from the relationships between the company and its stakeholders [57]. In this way, it will be possible to identify the values that give access to a new adjustment of the stakeholder theory [58]. In addition, a new concept of value creation, shared value creation, has appeared in recent years [59]. This concept implies the idea of generating value balanced with the environment. In other words, the company must create value for itself and the environment.

Related to the theory of legitimacy, this theory arises from the existence of a social contract between the company and society, starting with the business of an ethical nature [60]. These become established in the organization if the specific objectives are in line with social norms [61]. The company must legitimize them to stakeholders by issuing results reports [62]. For this reason, CSR's memoirs are indispensable for confirming their actions with legitimacy [63]. In addition, some companies have adopted the SLO (Social License to Operate) model as a fundamental tool for the management of their CSR [64] and its reputation.

It is also envisioned, from the accounting theory, that information issued from this is influenced by concepts that are imposed in the social context where the organization is located [65]. Around this hypothesis, its purpose is ultimately to normalize individual behaviors and techniques that legitimize their actions [66] in order to make natural interests in the company prevail [67].

Furthermore, the economic policy theory indicates that, in addition to the self-regulation supported by an organization [68], it will also comply with the rules imposed by the State [69]. In this case, its voluntary action [70] will not prevail.

In the institutional theory, the institutional analysis of CSR [71] is interpreted. In this approach, it is defined as a controlled process derived from the institutional capacity conferred on it by the stakeholders [72] in decision-making [73] and in the costs of the actions involved [74].

From the perspective of the Resource Dependency Theory, the organization seeks to maximize its power based on resource exchange $[75,76]$. To this end, the search for relations with stakeholders is prioritized to obtain the necessary resources in their activity $[77,78]$. This theory is solid with the institutional theory $[79,80]$ since organizations are persistent in adapting to continuous demands [81] and must interact to meet a broad scale of interests [82].

The incompatibility between economic development and ecological balance in the traditional economic system [83-85] is evident. The theory of sustainability [86] appears to indicate that the policies and actions necessary to achieve economic growth [87] must respect the environment and be socially equitable $[88,89]$. In addition, CSR has gone from being considered detrimental to a company's financial profitability to a potential competitive advantage, at least in the long term [90-92].

By determining a company's values, strategies can be established that meet and respond to social and stakeholder demands. In this sense, an organization will meet expectations and be considered legitimate if it meets the interests associated with social, economic and environmental dimensions. 
From this perspective, the approach to sustainability in CSR has been extensively researched over the past few years. Thus, it has been studied from a European corporate perspective [93], in practice and policy in Asian luxury hotels [94], in the practice reports issued by India's major companies [95], in the effectiveness of balanced scorecard in family hotels [43], or in the performance indicators and in the reporting of sustainability in Hungary [96]. There are studies directed towards analyzing the role of CSR in sustainability [1], CSR's strategy on the environmental dimension of sustainability [97], an integrated approach to CSR and corporate sustainability [98], the telecommunications industry's participation in the CSR's sustainable approach [99], or the expectations of Chinese consumers in corporate communication on CSR and sustainability [100].

CSR research also includes the rest of the dimensions. Thus, the social approach has been studied, among others, from the perspective of gender equality [44,101,102], or in the analysis of CSR reports produced by international contracting companies [103].

CSR's economic approach has been addressed in various research, such as the role of CSR communication in the profitability on investment in marketing (business returns) [104], in the vision of Islamic banking [105], management research [106], the relationship between CSR and innovation [107], and in the analysis of their historical connection with financial markets [108].

As for the revisions of the literature carried out in the line of Sustainability/CSR research, there are works related to its management accounting [109], an analysis of global corporate sustainability reports [110], sustainable global supply [111], social responsibility in the mining industry [112], the effect of the CSR on companies with profits [113], CSR in marketing research [114], CSR and organizational psychology [115], and an approximation to the connection and mismatch arguments between CSR and corporate sustainability [116].

It is necessary to highlight the work of the role that the CSR plays in family companies where management and decision-making are carried out for succession issues and social responsibility in these organizations is a value that is passed down between generations. Due to the fact that its economic activity is carried out in a given region, its responsibility is focused on protecting the environment in this context and in the development of the collectivity associated with the most immediate environment $[117,118]$. In addition, because their actions are governed by the principles of protecting customs and territory, they are considered as sources of employment, wealth and innovation [119].

\section{Materials and Methods}

Scientometrics is the science that studies scientific production to measure and analyze it. It is also known as the scientific and empirical study of science and its results. In practice, there is a significant overlap between scientometrics and other scientific fields: bibliometry, information systems, information science and scientific politics [120]. It is based mainly on the works of Dereck J. de Solla Price and Eugene Garfield, who founded the Institute for Scientific Information (ISI) in 1960. Later, in 1998, he created the journal Scientometrics.

On the other hand, bibliometry is a part of scientometrics that applies mathematical and statistical methods to scientific literature and to the authors that produce it with the aim of studying and analyzing scientific activity. The instruments used to measure aspects of scientific activity are bibliometric indicators, which are measures that provide information on the results of scientific activity in any of its manifestations [121,122]. It was introduced by E. Garfield in the mid-20th century and has since become widespread in scientific research and has contributed to reviewing knowledge in multiple disciplines for decades. Thus, scientometrics and bibliometry have evolved from reflection on scientific development and the availability of numerous databases for the researcher.

The objective of this work is to show an insight into the overall research dynamics and the state of the issue regarding the outcome in companies of CSR actions on sustainability. To achieve the proposed objective, a quantitative analysis has been carried out, using bibliometry. Likewise, the objective of this method is to identify, organize, and analyze trends in the research topic. In recent decades it has 
contributed to the review of scientific knowledge and has been used successfully in various scientific fields, such as medicine, engineering, economics, administration, finance, education, biology, and ecology [123-130].

The method used was to perform a full search on the Scopus database, using a search string with the terms "corporate social responsibility" and "sustainability" to examine the subfields of the title, summary, and keywords over a period of 18 years, from 2001 to 2018 [131-133]. The sample of articles analyzed was obtained through a search within August 2019, which included only scientific articles, both in open and non-open access. The final sample included a total of 1832 documents. The variables analyzed were year of publication, thematic area, journal, author, country of affiliation of the author, institution where the author is affiliated, and keywords that define the publication.

In this study, the indicators of scientific production analyzed have been the distribution for years of published articles and the productivity of authors, countries, and institutions. The quality indicators used were the $\mathrm{H}$ index, the count of the number of appointments and the indicator that measures the quality of the scientific journals included in Scopus, SCImago Journal Rank (SJR). In addition, the collaborative structure indicators, which measure the links between authors and countries, have been analyzed through network mapping and processing tools due to their reliability and suitability in the bibliometric analysis [134-137]. The results obtained are useful for researchers, academics, analysts, managers, and other stakeholders since scientific activity in this field of research have been evaluated.

\section{Results and Discussion}

\subsection{Evolution of Scientific Production}

Table 2 shows the evolution of the main features of the articles published on CSR's sustainable approach from 2001 to 2018. In this period, the interest in researching the CSR-sustainability relationship has increased, especially in the last six years, as seen in the variables analyzed. If only 14 articles on this subject were published in 2001-2003, in the last three years analyzed (2015-2018) the number amounted to 760 , or almost 55 times more. The increase in the number of publications is particularly accentuated in the latter three years, where $41.5 \%$ of the total articles published in the period analyzed have been published. The year in which most publications have been produced is 2018, with 304 articles.

Table 2. Major characteristics of the articles of CSR and sustainability research from 2001-2018.

\begin{tabular}{ccccccc}
\hline Period & A & AU & C & TC & TC/A & J \\
\hline $2001-2003$ & 14 & 22 & 8 & 917 & 65.5 & 13 \\
$2004-2006$ & 48 & 88 & 20 & 3314 & 69.0 & 32 \\
$2007-2009$ & 173 & 304 & 32 & 7149 & 41.3 & 110 \\
$2010-2012$ & 308 & 630 & 49 & 8884 & 28.8 & 190 \\
$2013-2015$ & 529 & 1179 & 72 & 7281 & 13.8 & 306 \\
$2016-2018$ & 760 & 1859 & 83 & 2816 & 3.7 & 352 \\
\hline
\end{tabular}

A: the annual number of articles, AU: number of authors, C: number of countries, TC: the annual number of citations in total articles, TC/A: average citations, J: number of journals.

Figure 1 shows the evolution in the number of articles and their percentage of variation between each triennium studied. In addition to the considerable increase in the number of articles published in the last six years, it highlights the percentage of growth produced in the second and third period analyzed, i.e. in 2004-2006 and 2007-2009. The percentage increase in the number of publications in 2007-2009 is due to the fact that it is the first three-year increase in 100 articles (173). 


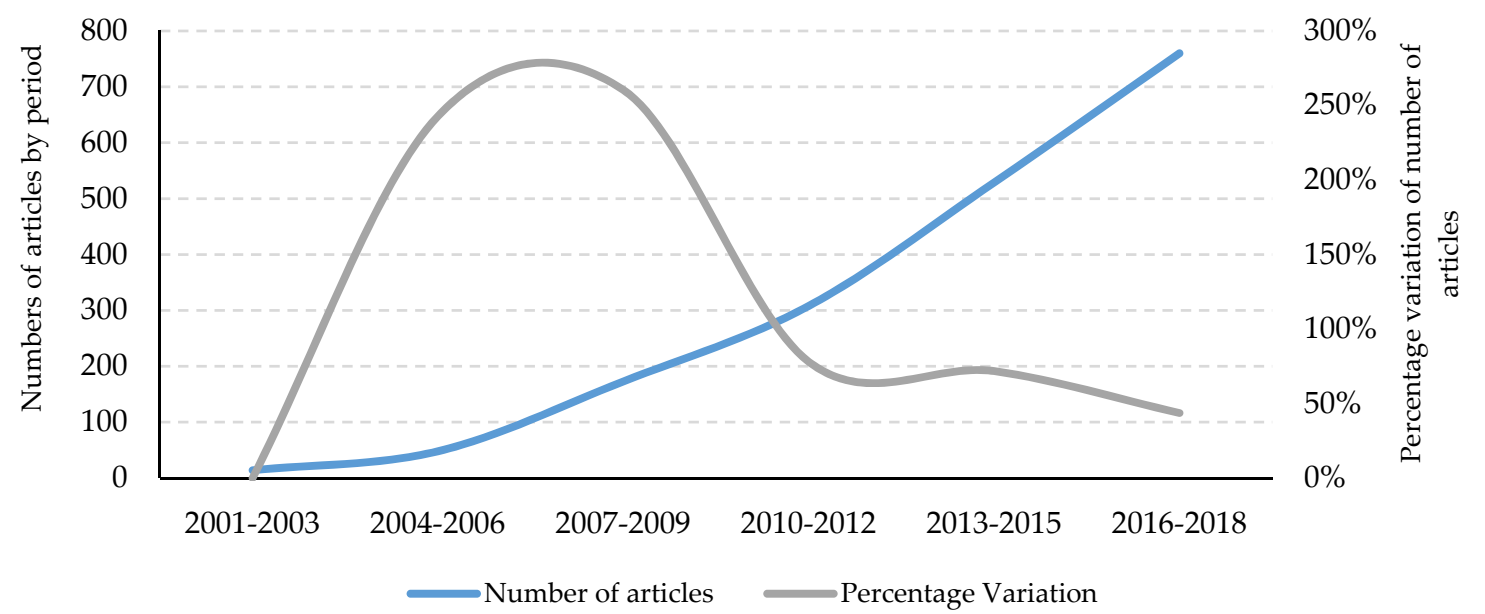

Figure 1. Evolution of the number of articles and percentage of variation between trienniums.

As with the number of articles, the total number of authors has also increased during the period analyzed. The last triennium (2016-2018) concentrates $40.1 \%$ of total authors for the 18-year period, or 3784. It is noted that the number of authors who published in this field of research between 2001-2003 was 22, amounting to 1859 authors in the triennium 2016-2018. This is a larger increase than experienced in the number of articles published because the average number of authors per article has also increased. Thus, in 2001-2003 the average number of authors per article stood at 1.6 authors per article, while in the last period, 2016-2018, it increased to 2.4 authors per article.

The number of countries involved in the publication of articles on this subject of research has increased from eight in the 2001-2003 triennium to 83 in the last period analyzed. Throughout the period analyzed, 2001-2018, the total number of countries that have contributed to the publication of articles on CSR's sustainable approach amounts to 91.

The number of quotes grew exponentially, from the first period with 917 to the fourth triennium analyzed, 2010-2012, with 8884. Since this three-year period, the total number of citations of the total articles has been decreasing with 7281 in the following period and with 2816 in the last triennium. This is due to the fact that the published articles, or those corresponding to the last 6 years, will receive a greater number of citations in the coming years due to their recent publication and impact and their distribution in open access $[138,139]$. This is related to the average annual number of citations per item. This average has been decreasing from 65.5 in the first triennium (2001-2003) to 3.7 in the last period (2016-2018).

Finally, the number of journals publishing articles on CSR's sustainable approach increased from 13 in the first period to 352 over the last three-year period analyzed.

\subsection{Distribution of Publications by Subject Area and Journal}

During the time period analyzed, 2001-2018, there are several categories where studies related to the link between CSR and sustainability have been found. According to the Scopus classification, there are a total of 23 thematic areas in which the 1832 articles analyzed are classified. It is necessary to clarify that the same article may be classified in more than one category, depending on the interest of the author and the publisher.

Figure 2 presents how the thematic classification of articles on CSR and sustainability has evolved in the period of 2001-2018. The Business, Management, and Accounting category is the most prominent throughout the period studied. In this category, 31\% of published articles were based on CSR and sustainability. It is then followed by the Social Sciences category, with $21 \%$. Other categories included Environmental Science (14\%), Economics, Econometrics and Finance (10\%) and Energy (7\%) are the following categories in order of importance. Thus, the five most important categories represented in Figure 2, represent $83 \%$ of the documents published in this field of research from 2001-2018. Except for 
Engineering (5.1\%) and Arts and Humanities (4\%) categories, the rest of the subject areas did not reach $2 \%$ of published works.

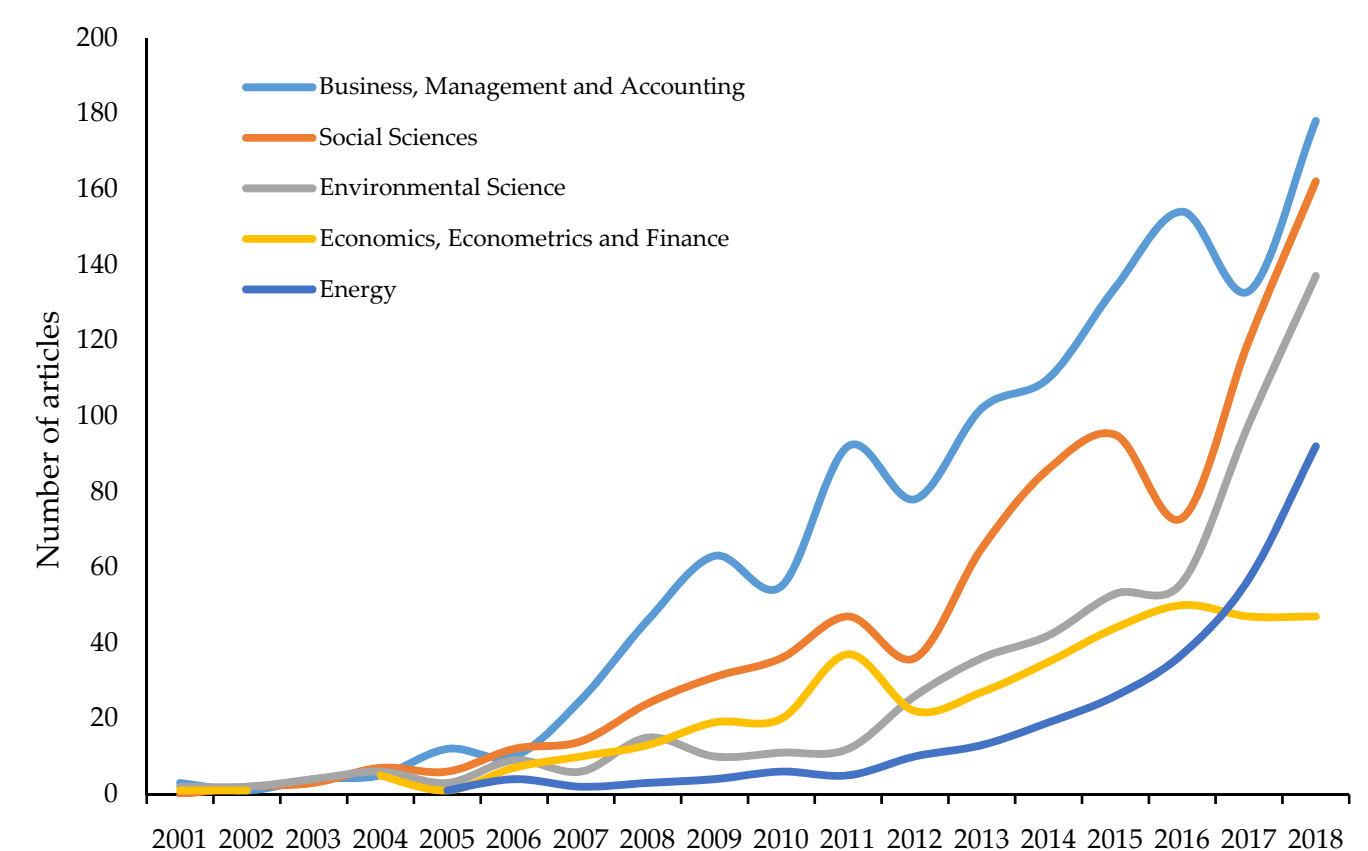

Figure 2. Comparisons of the growth trends of subject areas on CSR and sustainability research from 2001 to 2018.

The association of publications in this field of research, to the Business, Management, and Accounting and Social Sciences categories makes sense given the CSR is closely related to the management of stakeholder relations and dependence on their actions with environmental factors $[28,54,140]$.

Table 3 shows the characteristics of the articles of the main journals in the publication on the sustainable approach of corporate social responsibility. In the selection of the 20 journals with the highest number of articles published on the subject of research, $51 \%$ of journals belong to the first quartile of the SJR index, SCImago Journal Rank 2017. Over the years the issue of the link between CSR and sustainability has been of interest to more journals and more authors as evidenced by the growth in the number of articles and the variety of journals interested. 
Table 3. The most prolific journals in the number of articles on CSR and sustainability research from 2001 to 2018.

\begin{tabular}{|c|c|c|c|c|c|c|c|c|c|c|c|c|c|}
\hline \multirow{2}{*}{ Journal } & \multirow{2}{*}{ A } & \multirow{2}{*}{ TC } & \multirow{2}{*}{ TC/A } & \multirow{2}{*}{$\mathrm{H}(\mathrm{A})$} & \multirow{2}{*}{$\mathbf{H}(\mathrm{J})$} & \multirow{2}{*}{ SJR * } & \multirow{2}{*}{ C } & \multicolumn{6}{|c|}{$\mathbf{R}(\mathrm{A})$} \\
\hline & & & & & & & & 2001-2003 & 2004-2006 & $2007-2009$ & 2010-2012 & 2013-2015 & $2016-2018$ \\
\hline Journal of Business Ethics & 111 & 4115 & 37.07 & 42 & 147 & $\begin{array}{l}1.860 \\
(\mathrm{Q} 1)\end{array}$ & Nethlands & $8(1)$ & $1(5)$ & $1(18)$ & $1(31)$ & $1(28)$ & $4(28)$ \\
\hline Sustainability & 111 & 418 & 3.77 & 12 & 53 & $\begin{array}{l}0.549 \\
(\mathrm{Q} 2)\end{array}$ & Switzerland & 0 & 0 & 0 & 0 & $6(13)$ & $1(98)$ \\
\hline Journal of Cleaner Production & 95 & 3347 & 35.23 & 30 & 150 & $\begin{array}{l}1.620 \\
(\mathrm{Q} 1)\end{array}$ & Netherlands & 0 & $8(2)$ & $9(3)$ & $3(7)$ & $2(23)$ & $2(60)$ \\
\hline $\begin{array}{l}\text { Corporate Social Responsibility } \\
\text { and Environmental Management }\end{array}$ & 70 & 1751 & 25.01 & 27 & 58 & $\begin{array}{l}1.670 \\
(\mathrm{Q} 1)\end{array}$ & USA & $2(1)$ & $3(3)$ & $4(5)$ & 2(11) & $3(21)$ & $3(29)$ \\
\hline $\begin{array}{l}\text { Business Strategy and the } \\
\text { Environment }\end{array}$ & 48 & 1348 & 28.08 & 24 & 84 & $\begin{array}{l}2.166 \\
(\mathrm{Q} 1)\end{array}$ & USA & 0 & $12(1)$ & $5(4)$ & $7(5)$ & $4(15)$ & $5(23)$ \\
\hline Social Responsibility Journal & 35 & 208 & 5.94 & 9 & 23 & $\begin{array}{l}0.432 \\
(\mathrm{Q} 2)\end{array}$ & $\begin{array}{l}\text { United } \\
\text { Kingdom }\end{array}$ & 0 & 0 & $3(7)$ & $6(6)$ & $5(15)$ & $11(7)$ \\
\hline $\begin{array}{l}\text { Sustainability Accounting } \\
\text { Management and Policy Journal }\end{array}$ & 20 & 152 & 7.60 & 8 & 18 & $\begin{array}{l}0.778 \\
(\mathrm{Q} 1)\end{array}$ & $\begin{array}{l}\text { United } \\
\text { Kingdom }\end{array}$ & 0 & 0 & 0 & $4(7)$ & 11(5) & $8(8)$ \\
\hline Corporate Governance (Bingley) & 14 & 77 & 5.50 & 6 & 47 & $\begin{array}{l}0.430 \\
(\mathrm{Q} 2)\end{array}$ & $\begin{array}{l}\text { United } \\
\text { Kingdom }\end{array}$ & 0 & 0 & 0 & $22(2)$ & $8(7)$ & $16(5)$ \\
\hline Sustainable Development & 14 & 198 & 14.14 & 8 & 51 & $\begin{array}{l}0.989 \\
(\mathrm{Q} 1)\end{array}$ & USA & 0 & 0 & $11(3)$ & 0 & $12(5)$ & $15(6)$ \\
\hline Corporate Governance & 13 & 397 & 30.54 & 11 & 70 & $\begin{array}{l}1.432 \\
(\mathrm{Q} 1)\end{array}$ & $\begin{array}{l}\text { United } \\
\text { Kingdom }\end{array}$ & 0 & $14(1)$ & $2(10)$ & $21(2)$ & 0 & 0 \\
\hline $\begin{array}{c}\text { Corporate Ownership and } \\
\text { Control }\end{array}$ & 13 & 16 & 1.23 & 2 & 16 & $\begin{array}{l}0.155 \\
(\mathrm{Q} 3)\end{array}$ & Ukraine & 0 & 0 & $38(1)$ & $23(2)$ & $7(9)$ & 137(1) \\
\hline Amfiteatru Economic & 12 & 78 & 6.50 & 6 & 16 & $\begin{array}{l}0.237 \\
(\mathrm{Q} 2)\end{array}$ & Romania & 0 & 0 & $24(1)$ & $5(6)$ & $29(2)$ & $24(3)$ \\
\hline Quality Access to Success & 12 & 12 & 1.00 & 3 & 19 & $\begin{array}{l}0.233 \\
(\mathrm{Q} 3)\end{array}$ & Romania & 0 & 0 & 0 & $16(3)$ & $69(2)$ & $10(7)$ \\
\hline Organization and Environment & 11 & 199 & 18.09 & 7 & 48 & $\begin{array}{l}2.605 \\
(\mathrm{Q} 1)\end{array}$ & USA & 0 & 0 & 0 & 0 & $10(5)$ & $14(6)$ \\
\hline Business and Society & 10 & 202 & 20.20 & 7 & 64 & $\begin{array}{l}2.346 \\
(\mathrm{Q} 1)\end{array}$ & USA & 0 & 0 & 13(2) & $64(1)$ & 0 & $9(7)$ \\
\hline Corporate Communications & 10 & 100 & 10.00 & 5 & 48 & $\begin{array}{l}0.470 \\
(\mathrm{Q} 2)\end{array}$ & $\begin{array}{l}\text { United } \\
\text { Kingdom }\end{array}$ & 0 & 0 & $6(4)$ & $73(1)$ & $35(2)$ & $26(3)$ \\
\hline Espacios & 10 & 2 & 0.20 & 1 & 12 & $\begin{array}{l}0.158 \\
(\mathrm{Q} 3)\end{array}$ & Venezuela & 0 & 0 & 0 & 0 & $41(2)$ & $7(8)$ \\
\hline Journal of Sustainable Tourism & 10 & 144 & 14.40 & 6 & 83 & $\begin{array}{l}1.365 \\
(\mathrm{Q} 1)\end{array}$ & $\begin{array}{l}\text { United } \\
\text { Kingdom }\end{array}$ & 0 & 0 & 20(2) & $149(1)$ & $232(1)$ & $12(6)$ \\
\hline Business Horizons & 9 & 443 & 49.22 & 6 & 67 & $\begin{array}{l}1.296 \\
(\mathrm{Q} 1)\end{array}$ & Netherlands & 0 & $5(2)$ & $30(1)$ & 0 & $32(2)$ & $18(4)$ \\
\hline $\begin{array}{l}\text { Developments in Corporate } \\
\text { Governance and Responsibility }\end{array}$ & 9 & 0 & 0.00 & 1 & 4 & $\begin{array}{l}0.124 \\
(\mathrm{Q} 4)\end{array}$ & $\begin{array}{l}\text { United } \\
\text { Kingdom }\end{array}$ & 0 & 0 & 0 & $79(1)$ & 0 & $6(8)$ \\
\hline
\end{tabular}

A: number of articles, R(A): rank position by number of articles, TC: number of citations for all articles, TC/A: number of citations by article, $\mathrm{H}(\mathrm{A})$ : $\mathrm{H}$ index in articles, $\mathrm{H}(\mathrm{J})$ : $\mathrm{H}$ index in journal

SJR: Scimago Journal Rank (quartile), C: country, $\left(^{*}\right)$ : The impact factor and quartiles (Q1 to Q4) are presented to refer to journal ranking within a subdiscipline using the SJR citation index. 
By country, among the top 20 journals in the graft publication are those of European origin: United Kingdom (7), Netherlands (3), Romania (2), Switzerland (1), and Ukraine (1). Those of American origin (5) are also the journals that have a better position in the SJR 2017 ranking.

The journal that has published more articles on the relationship between CSR and sustainability is the Journal of Business Ethics and Sustainability with 111. Each journal accounts for $6.1 \%$ the total articles published since 2001-2018.

Journal of Business Ethics has been the one with more trieniums occupying the first position in the ranking four of the six periods analyzed. This journal also stands out because it concentrates a great interest in the scientific community, as evidenced by the high number of citations gathered by its articles, 4115 , and for the average number of citations by published articles, with 37.07 citations per article. It is also the journal that presents the largest $\mathrm{H}$ index for the published articles on this topic of research, 42, which is quite far from the general $\mathrm{H}$ index of the journal, for all subjects, which stands at 147. Organization and Environment journal has the highest SJR impact factor: 2605 (Q1), followed by Business and Society, with 2346 (Q1), and Business Strategy and the Environment, with 2166.

However, it is important to note that the journal Sustainability, with its first article published on the subject of analysis in 2013, has become the journal with the largest number of articles on CSR/sustainability, with 98 documents of the total published (352) in the last triennium (2016-2018). These works account for $27.8 \%$ of the total articles on this subject that have been published in that triennium (2016-2018). However, this circumstance is not reflected in the number of citations due to recent work.

\subsection{Productivity of Authors, Institutions, and Countries}

Table 4 shows the main variables of the articles of the 10 most prolific authors in the publication on the sustainable approach of CSR during the period 2001-2018. The author who has published the most articles on the subject of research is Spaniard García-Sánchez of the University of Salamanca, with 11 documents, followed by Dutch Moratis of Breda University of Applied Sciences, with nine. Spaniard Moneva of the University of Zaragoza has published eight.

Table 4. The most prolific authors in number of articles on CSR and sustainability from 2001-2018.

\begin{tabular}{|c|c|c|c|c|c|c|c|c|}
\hline Author & A & $\mathrm{TC}$ & $\mathrm{TC} / \mathrm{A}$ & Institution & $\mathrm{C}$ & 1st $A$ * & Last A * & $\mathrm{H}$ index ${ }^{*}$ \\
\hline $\begin{array}{l}\text { García-Sánchez. } \\
\text { I.M. }\end{array}$ & 11 & 210 & 19.09 & $\begin{array}{l}\text { Universidad de } \\
\text { Salamanca }\end{array}$ & Spain & 2011 & 2018 & 6 \\
\hline Moratis. L. & 9 & 26 & 2.89 & $\begin{array}{l}\text { Breda University of } \\
\text { Applied Sciences }\end{array}$ & Netherlands & 2014 & 2018 & 5 \\
\hline Moneva. J.M. & 8 & 162 & 20.25 & $\begin{array}{c}\text { Universidad de } \\
\text { Zaragoza }\end{array}$ & Spain & 2007 & 2018 & 6 \\
\hline Fernandez-Feijoo. B. & 7 & 162 & 23.14 & Universidade de Vigo & Spain & 2014 & 2017 & 6 \\
\hline Seele. P. & 7 & 95 & 13.57 & $\begin{array}{l}\text { Università della } \\
\text { Svizzera italiana }\end{array}$ & Switzerland & 2014 & 2017 & 6 \\
\hline Albareda. L. & 6 & 177 & 29.50 & $\begin{array}{c}\text { Lappeenrannan } \\
\text { Teknillinen Yliopisto }\end{array}$ & Finland & 2007 & 2018 & 4 \\
\hline Costa. R. & 6 & 103 & 17.17 & $\begin{array}{l}\text { Università degli Studi } \\
\text { di Roma Tor Vergata }\end{array}$ & Italy & 2013 & 2018 & 5 \\
\hline
\end{tabular}

A: number of articles, TC: number of citations for all articles, TC/A: number of citations by article, C: country, 1st A: First article, Last A: Last article, $\mathrm{H}$ index: Hirsch index, $\left(^{*}\right)$ : in research topic.

However, the author with the highest number of citations on CSR/sustainability relation is Kolk, from the Netherlands, with a total of 642 , which also places him as the author with the highest average number of quotations per article, with 107. Schaltegger, from Germany, follows with 372 citations and an average of 53.14 citations per item. In addition, Kolk also stands out with the highest $\mathrm{H}$ index, six, 
in this case, just like five other authors. He is the second author in this ranking to publish his first article in 2008, after Albareda of Finland in 2007.

It is noteworthy the 10 most prolific authors in the publication of articles on this subject of research have European origin: Spain (4), Netherlands (2), and Germany, Switzerland, Finland, and Italy, with one. In addition, six authors published a final paper in 2018, the last year analyzed in this study, which indicates the importance and interest of the research topic.

Figure 3 shows the collaboration map among the leading authors who have published on the sustainable dimension of CSR, based on co-authorship. The different colors represent the different clusters formed by the working groups in the production of articles. The size of the circle varies depending on the number of articles of each author. The main authors are grouped into three clusters. Cluster 1 (red) stands for the collaboration between Muñoz-Torres and Rivera-Lirio, Fernández-Izquierdo, Ferrero-Ferrero, and Escrig-Olmedo. Group 2 (green) is led by Moneva, University of Zaragoza, along with Ortas, Alvarez, Gallego-Alvarez, and Garallar. Finally, the third cluster (blue) is led by Fernández-Feijoo, from the University of Vigo, which collaborates with Ruíz, Romero, García-Torea and De la Cuesta-González.

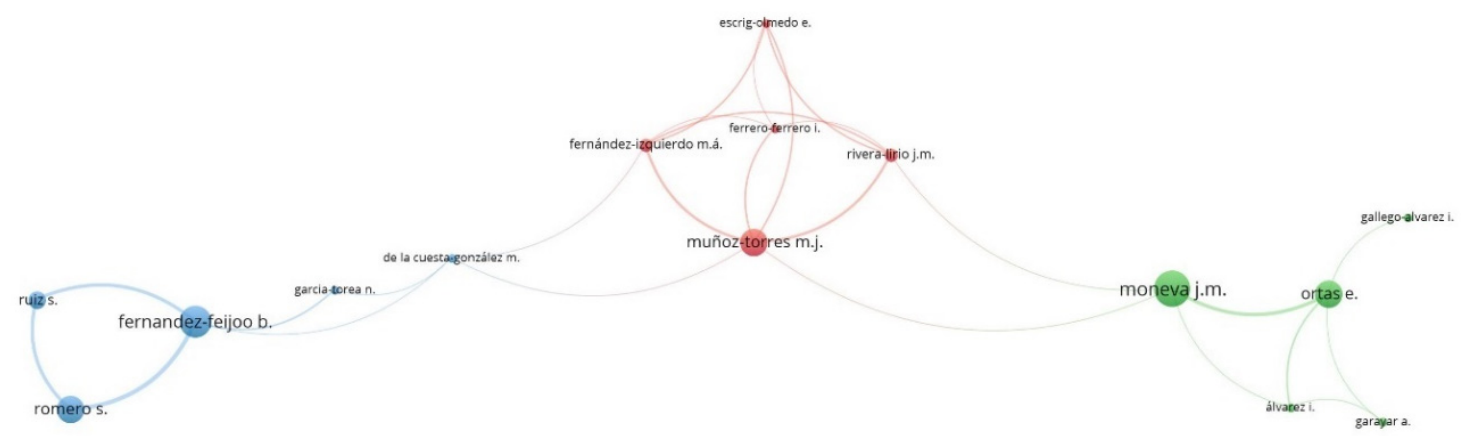

Figure 3. Network of cooperation based on co-authorship between authors from 2001 to 2018.

Table 5 shows the ten most prolific institutions in the publication of articles related to CSR's sustainable approach. Spain, with four institutions, is the country that has the largest presence in this ranking. Among them, the University of Salamanca is placed in the first position with 22 articles and 432 citations. This institution has the highest $\mathrm{H}$ index on the table with 11 along with the Danish Copenhagen Business School and the University of Granada in Spain.

Table 5. The most prolific institutions in number of articles on CSR and sustainability research from 2001-2018.

\begin{tabular}{|c|c|c|c|c|c|c|c|c|}
\hline Institution & $\mathrm{C}$ & A & TC & TC/A & $\mathrm{H}$ index & IC (\%) & TCIC & TCNIC \\
\hline Universidad de Salamanca & Spain & 22 & 432 & 19.64 & 11 & 4.5 & 0.00 & 20.57 \\
\hline $\begin{array}{l}\text { Wageningen University and } \\
\text { Research Centre }\end{array}$ & Netherlands & 18 & 127 & 7.06 & 8 & 44.4 & 6.50 & 7.50 \\
\hline $\begin{array}{l}\text { Copenhagen Business } \\
\text { School }\end{array}$ & Denmark & 17 & 560 & 32.94 & 11 & 52.9 & 22.44 & 44.75 \\
\hline Universidad de Zaragoza & Spain & 16 & 252 & 15.75 & 9 & 25.0 & 11.25 & 17.25 \\
\hline Universidad de Granada & Spain & 16 & 592 & 37.00 & 11 & 12.5 & 12.00 & 40.57 \\
\hline $\begin{array}{l}\text { Bucharest University of } \\
\text { Economic Studies }\end{array}$ & Romania & 16 & 78 & 4.88 & 6 & 12.5 & 3.50 & 5.07 \\
\hline University of Valencia & Spain & 15 & 152 & 10.13 & 4 & 26.7 & 1.25 & 13.36 \\
\hline $\begin{array}{c}\text { Leuphana Universität } \\
\text { Lüneburg }\end{array}$ & Germany & 15 & 716 & 47.73 & 10 & 33.3 & 9.20 & 67.00 \\
\hline Universiti Teknologi MARA & Malaysia & 13 & 176 & 13.54 & 6 & 30.8 & 32.00 & 5.33 \\
\hline University of Leeds & $\begin{array}{l}\text { United } \\
\text { Kingdom }\end{array}$ & 13 & 342 & 26.31 & 9 & 69.2 & 10.33 & 62.25 \\
\hline
\end{tabular}

C: country, A: number of articles, TC: number of citations for all articles, TC/A: number of citations by article, H index: Hirsch index in research topic, IC: percentage of articles made with international collaboration, TCIC: number of citations by article made with international collaboration, TCNIC: number of citations by article made without international collaboration. 
On the other hand, it is interesting to highlight the low international co-authorship of the articles of the Spanish institutions, especially in the case of Salamanca (4.5-percent). It is noted, for example, that the University of Leeds, United Kingdom, with almost half of the published articles of the Spanish (13), has more citations per article, 26.31 compared to 19.64. In addition, the English university has a very relevant international exposure, since $69.2 \%$ of the articles are made with authors from other countries. Otherwise, it is relevant that only in the case of Malaysia's Universiti Teknologi MARA, quotations from articles published with other countries (32) outperform average quotes written by Malaysian authors only (5.33).

Table 6 lists the main variables of the countries with the highest scientific output on the sustainable approach in the CSR during the period 2001-2018. First, there is the United States with a total of 343 articles and with the highest total number of citations, 8482 , i.e. an average of 24.73 citations for each article on the subject of research, representing the second-highest average of citations per article, after Canada (25.92). The United States also has the largest H index, with 50. The country with the second-highest number of articles is the United Kingdom with a total of 218, and also presents the second total number of citations, 4705 , and the $\mathrm{H}$ index, with 40 . This peculiarity indicates the interest of American and English publications on the link between CSR and sustainability.

Table 6. The most prolific countries in number of articles on CSR and sustainability research from 2001 to 2018.

\begin{tabular}{|c|c|c|c|c|c|c|c|c|c|c|}
\hline $\begin{array}{l}\text { United } \\
\text { States }\end{array}$ & 343 & 8482 & 24.73 & 50 & $1(4)$ & $1(3)$ & $1(34)$ & $1(72)$ & 1(101) & $1(129)$ \\
\hline $\begin{array}{l}\text { United } \\
\text { Kingdom }\end{array}$ & 218 & 4705 & 21.58 & 40 & 0 & 0 & $7(1)$ & $2(3)$ & $6(3)$ & $3(70)$ \\
\hline Spain & 198 & 3144 & 15.88 & 35 & 0 & 0 & $6(1)$ & $9(1)$ & $4(5)$ & $2(87)$ \\
\hline Canada & 98 & 2540 & 25.92 & 29 & 0 & 0 & 0 & $4(2)$ & $2(7)$ & $5(43)$ \\
\hline Germany & 87 & 2123 & 24.40 & 25 & 0 & 0 & $3(1)$ & $6(1)$ & 0 & $7(36)$ \\
\hline Netherlands & 85 & 2035 & 23.94 & 24 & 0 & 0 & $4(1)$ & $8(1)$ & 0 & $8(36)$ \\
\hline France & 61 & 852 & 13.97 & 15 & 0 & 0 & 0 & 0 & $8(2)$ & $13(24)$ \\
\hline China & 56 & 470 & 8.39 & 14 & 0 & 0 & 0 & $5(2)$ & $3(7)$ & $9(34)$ \\
\hline
\end{tabular}

A: number of articles, R(A): rank position by number of articles, TC: number of citations for all articles, TC/A: number of citations by article, $\mathrm{H}$ index: Hirsch index in research topic.

The United States has been at the forefront of the ranking of the most prolific countries in the production of articles on the subject of research throughout the period analyzed, thus highlighting its research power. After these two countries are Spain, Australia, and Italy, with 198, 118, and 102 articles respectively. In the last three-year period analyzed (2016-2018), Spain has moved to the second position and Italy was third in number of published articles on CSR's sustainable approach. These five countries, United States, United Kingdom, Spain, Australia, and Italy, are the main drivers of research on the subject of research since they have published $53 \%$ of the world's total articles.

The remaining five countries: Canada, Germany, Netherlands, France, and China, are placed with a smaller number of items. Of this group, Germany and the Netherlands are noticeable as they ranked third and fourth, respectively, in the period 2007-2009, and in the triennium 2013-2015, but did not publish any articles on this subject of research. In this area, they have gone from publishing 36 articles each in the last three-years analyzed, 2016-2018, occupying the seventh and eighth ranking position. It is also important to note that, of this second group of countries, Canada, Germany, and the Netherlands have the best citation averages per article right after the country leading this variable, the United States.

Table 7 shows the variables related to international collaboration between different countries. The countries with the highest percentage of international collaboration work are China with $75 \%$ (19 items), followed by France, with $60.7 \%$ (22), Canada with 50\% (24) and the United Kingdom with $49.5 \%$ (49). Spain is the country with the lowest percentage of international collaboration with $25.3 \%$ 
(26 articles). It is noteworthy that, with the exception of the Netherlands, France, and China, in all the ranking countries the number of citations of the works that have been subject to international co-authorship is greater than those submitted by the articles without such collaborations.

Table 7. The most prolific countries and international collaboration from 2001 to 2018.

\begin{tabular}{|c|c|c|c|c|c|}
\hline \multirow{2}{*}{ Country } & \multirow{2}{*}{ NC } & \multirow{2}{*}{ Main Collaborators } & \multirow{2}{*}{ IC (\%) } & \multicolumn{2}{|c|}{ TC/A } \\
\hline & & & & IC & NIC \\
\hline $\begin{array}{l}\text { United } \\
\text { States }\end{array}$ & 41 & $\begin{array}{l}\text { Canada, United Kingdom, China, } \\
\text { Spain, France }\end{array}$ & $33.5 \%$ & 19.92 & 27.15 \\
\hline $\begin{array}{l}\text { United } \\
\text { Kingdom }\end{array}$ & 49 & $\begin{array}{c}\text { Unites States, China, Germany, } \\
\text { France, Italy }\end{array}$ & $49.5 \%$ & 18.46 & 24.65 \\
\hline Spain & 26 & $\begin{array}{l}\text { Unites States, Mexico, Portugal, } \\
\text { United Kingdom, Brazil }\end{array}$ & $25.3 \%$ & 14.30 & 16.41 \\
\hline Australia & 25 & $\begin{array}{l}\text { Unites States, United Kingdom, } \\
\text { China, Malaysia, Netherlands }\end{array}$ & $28.8 \%$ & 11.76 & 24.31 \\
\hline Italy & 23 & $\begin{array}{l}\text { United Kingdom, Unites States, } \\
\text { Denmark, Belgium, China }\end{array}$ & $33.3 \%$ & 7.12 & 7.84 \\
\hline Canada & 24 & $\begin{array}{l}\text { United States, France, United } \\
\text { Kingdom, Brazil, Germany }\end{array}$ & $50.0 \%$ & 19.71 & 32.12 \\
\hline Germany & 29 & $\begin{array}{l}\text { United Kingdom, France, } \\
\text { Switzerland, United States, Austria }\end{array}$ & $41.4 \%$ & 16.31 & 30.12 \\
\hline Netherlands & 22 & $\begin{array}{l}\text { Belgium, United Kingdom, Finland, } \\
\text { Australia, Denmark }\end{array}$ & $38.8 \%$ & 27.88 & 21.44 \\
\hline France & 22 & $\begin{array}{l}\text { United Kingdom, Unites States, } \\
\text { Canada, Germany, Belgium }\end{array}$ & $60.7 \%$ & 15.35 & 11.83 \\
\hline China & 19 & $\begin{array}{l}\text { United States, United Kingdom, } \\
\text { Australia, Hong Kong, Pakistan }\end{array}$ & $75.0 \%$ & 8.76 & 7.29 \\
\hline
\end{tabular}

NC: number of collaborators, IC: percentage of articles made with international collaboration, TC/A: number of citations by article, IC: international collaboration, NIC: no international collaboration.

The most prolific countries in the study of the research topic, since the last few years, are developing research on CSR in the controversial sectors activity, such as those related to armament companies, nuclear power plant construction companies, manufacturing companies of warplanes and missiles, companies that manufacture armoured vehicles, nuclear submarines and guidance systems for nuclear missiles, or companies dedicated to military electronics, flight simulators, shooting systems and electronic defense [141]. On the other hand, research is also being carried out on the organizations' capacities to face a constantly changing environment, in relation to the development of sustainability as an ecological capacity [142,143], and on the contribution to the transparency of the reports of the financial performance driven by institutional pressures or differentiation strategies [144].

Figure 4 shows a collaboration map between major countries based on the co-authorship of their authors. The different colors represent the different clusters formed by the groups of countries and the size of the circle varies depending on the number of items in each country. Thus, the greater the circle of each country, the greater the number of items whose authorship it represents. Countries with more than five contributions have been grouped into eight clusters. 


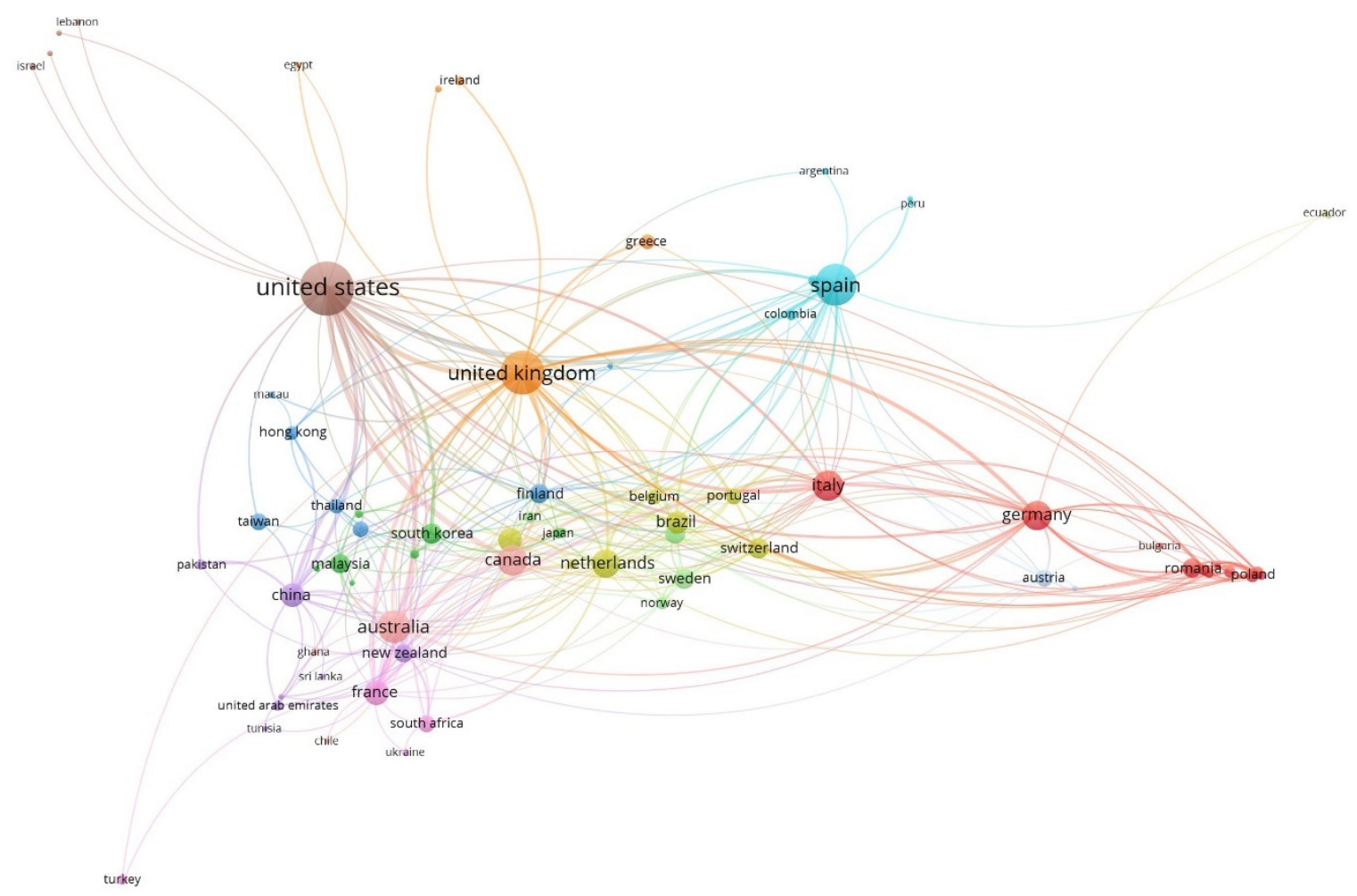

Figure 4. Network of cooperation based on co-authorship between countries from 2001 to 2018.

Cluster 1 includes 10 countries: Italy, Germany, Romania, Hungary, Czech Republic, Lithuania, Slovakia, Poland, Austria, and Croatia. Group 2, as large as Cluster 1, is led by Australia, which shares works with China, Finland, Australia, Ghana, and Thailand, among others. Cluster 3 is led by the Netherlands and includes countries such as Belgium, Brazil, Switzerland, and Portugal. Cluster 4 is headed by the United States and includes Denmark, Malaysia, Iran, Nigeria, South Korea, and Bangladesh. The fifth cluster, led by France, includes Ukraine, Pakistan, South Africa, and New Zealand. Cluster 6 consists of Canada, Japan, Norway, and Sweden. Group 7 is led by Spain and includes Mexico, Ecuador, and Colombia. Finally, Cluster 8, led by the United Kingdom, contains Greece, Ireland, and Turkey.

The international cooperation based on co-authorship has evolved, mainly, in the last decade in the CSR paradigm and its link with the sustainable dimension, articulating a discourse in this cooperation that places the organization as the key agent for the alliance between sustainable development and public politics $[145,146]$.

\subsection{Keywords Analysis}

Table 8 lists the 20 most frequently used keywords in the 1832 articles on CSR's sustainable approach during the period 2001-2018. The relationship for the entire period is shown, as well as for the various three-year subperiods in which the considered time frame of 18 years can be divided. 
Table 8. Main keywords in CSR and sustainability research during 2001-2018.

\begin{tabular}{|c|c|c|c|c|c|c|c|c|c|c|c|c|c|c|}
\hline \multirow{2}{*}{ Keyword } & \multicolumn{2}{|c|}{ 2001-2018 } & \multicolumn{2}{|c|}{$2001-2003$} & \multicolumn{2}{|c|}{ 2004-2006 } & \multicolumn{2}{|c|}{ 2007-2009 } & \multicolumn{2}{|c|}{$2010-2012$} & \multicolumn{2}{|c|}{ 2013-2015 } & \multicolumn{2}{|c|}{ 2016-2018 } \\
\hline & $\mathbf{A}$ & $\%$ & $\mathbf{R}(\mathrm{A})$ & $\%$ & $\mathbf{R}(\mathrm{A})$ & $\%$ & $\mathbf{R}(\mathrm{A})$ & $\%$ & $\mathbf{R}(\mathrm{A})$ & $\%$ & $\mathbf{R}(\mathrm{A})$ & $\%$ & $\mathbf{R}(\mathrm{A})$ & $\%$ \\
\hline Corporate Social Responsibility & 1175 & $64.1 \%$ & $1(6)$ & $42.9 \%$ & $1(22)$ & $45.8 \%$ & $1(115)$ & $66.5 \%$ & 1(205) & $66.6 \%$ & 1(335) & $63.3 \%$ & $1(492)$ & $64.7 \%$ \\
\hline Sustainability & 812 & $44.3 \%$ & $2(4)$ & $28.6 \%$ & 2(18) & $37.5 \%$ & $2(62)$ & $35.8 \%$ & 2(128) & $41.6 \%$ & $2(243)$ & $45.9 \%$ & $2(357)$ & $47.0 \%$ \\
\hline Sustainable Development & 405 & $22.1 \%$ & $3(3)$ & $3(3)$ & $3(13)$ & $27.1 \%$ & $3(43)$ & $24.9 \%$ & $3(60)$ & $19.5 \%$ & $3(119)$ & $22.5 \%$ & $3(167)$ & $22.0 \%$ \\
\hline CSR & 166 & $9.1 \%$ & 0 & \#N/D & $14(2)$ & $4.2 \%$ & $5(14)$ & $8.1 \%$ & $4(28)$ & $9.1 \%$ & $6(42)$ & $7.9 \%$ & $5(80)$ & $10.5 \%$ \\
\hline Corporate Social Responsibilities (CSR) & 158 & $8.6 \%$ & 0 & 0 & 0 & \#N/D & $28(5)$ & $2.9 \%$ & $22(7)$ & $2.3 \%$ & $4(51)$ & $9.6 \%$ & $4(95)$ & $12.5 \%$ \\
\hline Corporate Social Responsibility (CSR) & 111 & $6.1 \%$ & $21(1)$ & $7.1 \%$ & $5(5)$ & $5(5)$ & $18(6)$ & $3.5 \%$ & $9(13)$ & $4.2 \%$ & $7(28)$ & $5.3 \%$ & $7(58)$ & $7.6 \%$ \\
\hline Corporate Strategy & 109 & $5.9 \%$ & $4(2)$ & $14.3 \%$ & $4(6)$ & $12.5 \%$ & $4(15)$ & $8.7 \%$ & $5(23)$ & $7.5 \%$ & $5(50)$ & $9.5 \%$ & $42(13)$ & $1.7 \%$ \\
\hline Stakeholder & 100 & $5.5 \%$ & 0 & 0 & $34(2)$ & $34(2)$ & $39(4)$ & $2.3 \%$ & $17(9)$ & $2.9 \%$ & $9(23)$ & $4.3 \%$ & $6(62)$ & $8.2 \%$ \\
\hline Economic And Social Effects & 90 & $4.9 \%$ & $6(2)$ & $6(2)$ & $9(3)$ & $6.3 \%$ & $11(7)$ & $4.0 \%$ & $15(10)$ & $3.2 \%$ & $12(21)$ & $4.0 \%$ & $8(47)$ & $6.2 \%$ \\
\hline Corporate Sustainability & 83 & $4.5 \%$ & $5(2)$ & $5(2)$ & $86(1)$ & $2.1 \%$ & $19(6)$ & $3.5 \%$ & $10(13)$ & $4.2 \%$ & $8(26)$ & $4.9 \%$ & $10(35)$ & $4.6 \%$ \\
\hline Sustainability Reporting & 83 & $4.5 \%$ & $66(1)$ & $66(1)$ & 0 & \#N/D & $25(6)$ & $3.5 \%$ & $11(13)$ & $4.2 \%$ & $10(23)$ & $4.3 \%$ & $9(39)$ & $5.1 \%$ \\
\hline Social Responsibility & 66 & $3.6 \%$ & 0 & 0 & $12(3)$ & $6.3 \%$ & $31(5)$ & $2.9 \%$ & $8(14)$ & $4.5 \%$ & $13(21)$ & $4.0 \%$ & $15(23)$ & $3.0 \%$ \\
\hline Environmental Management & 64 & $3.5 \%$ & $30(1)$ & $7.1 \%$ & $19(2)$ & $4.2 \%$ & $12(7)$ & $4.0 \%$ & 19(8) & $2.6 \%$ & $14(20)$ & $3.8 \%$ & $13(26)$ & $3.4 \%$ \\
\hline Corporate Governance & 62 & $3.4 \%$ & 0 & $0.0 \%$ & 0 & 0 & $8(8)$ & $4.6 \%$ & $13(11)$ & $3.6 \%$ & $11(22)$ & $4.2 \%$ & $18(21)$ & $2.8 \%$ \\
\hline Ethics & 62 & $3.4 \%$ & 0 & $0.0 \%$ & $21(2)$ & $21(2)$ & $50(3)$ & $1.7 \%$ & $6(18)$ & $5.8 \%$ & $16(16)$ & $3.0 \%$ & $14(23)$ & $3.0 \%$ \\
\hline Stakeholders & 60 & $3.3 \%$ & 0 & $0.0 \%$ & 0 & \#N/D & $24(6)$ & $3.5 \%$ & $7(15)$ & $4.9 \%$ & $15(20)$ & $3.8 \%$ & $23(19)$ & $2.5 \%$ \\
\hline Supply Chain Management & 52 & $2.8 \%$ & 0 & $0.0 \%$ & $38(2)$ & $38(2)$ & $10(8)$ & $4.6 \%$ & $16(10)$ & $3.2 \%$ & $32(9)$ & $1.7 \%$ & $16(23)$ & $3.0 \%$ \\
\hline Business & 51 & $2.8 \%$ & 0 & $0.0 \%$ & $50(1)$ & $2.1 \%$ & $26(5)$ & $2.9 \%$ & $31(5)$ & $1.6 \%$ & $65(6)$ & $1.1 \%$ & $11(34)$ & $4.5 \%$ \\
\hline Business Ethics & 50 & $2.7 \%$ & 0 & $0.0 \%$ & 13(2) & $4.2 \%$ & $7(11)$ & $6.4 \%$ & $12(11)$ & $3.6 \%$ & $23(11)$ & $2.1 \%$ & $32(15)$ & $2.0 \%$ \\
\hline Decision Making & 48 & $2.6 \%$ & 0 & $0.0 \%$ & $90(1)$ & $0.0 \%$ & $20(6)$ & $3.5 \%$ & $50(4)$ & $1.3 \%$ & $24(11)$ & $2.1 \%$ & $12(26)$ & $3.4 \%$ \\
\hline
\end{tabular}

A: number of articles, $R(A)$ : rank position, \%: percentage of articles in which it appears, \#N/D: not data. 
The terms Corporate Social Responsibility, in 1175 documents, and Sustainability, in 812, occupy the first two positions throughout the period analyzed. They are followed by the term Sustainable Development in 405 articles since the revised literature it is considered to be synonymous with Sustainability $[147,148]$. On the other hand, the acronym CSR occupies the fourth position, a term used in 166 articles, and begins to be used from the second triennium (2004-2006). The composition of Corporate Social Responsibility, plural and singular, with the acronym CSR, are placed in the following positions with 111 and 109 articles, respectively. It is also noteworthy that the Concept Corporate Sustainability ranks tenth, with 83 articles, and $42.1 \%$ of these in the last period analyzed (2016-2018).

Figure 5 represents the network map for the keywords in the research articles on CSR and sustainability link for the period 2001-2018. The color of the nodes is used to differentiate the different groups or clusters according to the number of co-occurrences, while their size varies depending on the number of repetitions. Some lines of research developed by different communities or groupings have been detected. Six main lines of research are distinguished, which are grouped under the terms "Sustainable development," "Performance assessment," "Sustainability Reporting," "Globalization," "Corporate strategy", and "Decision-Making". These lines of research bring together all the concepts related to the sustainable approach of Corporate Social Responsibility, since it includes dynamics related to sustainable development in a globalized and connected world [149] and with management implying the active role of the organization [150].

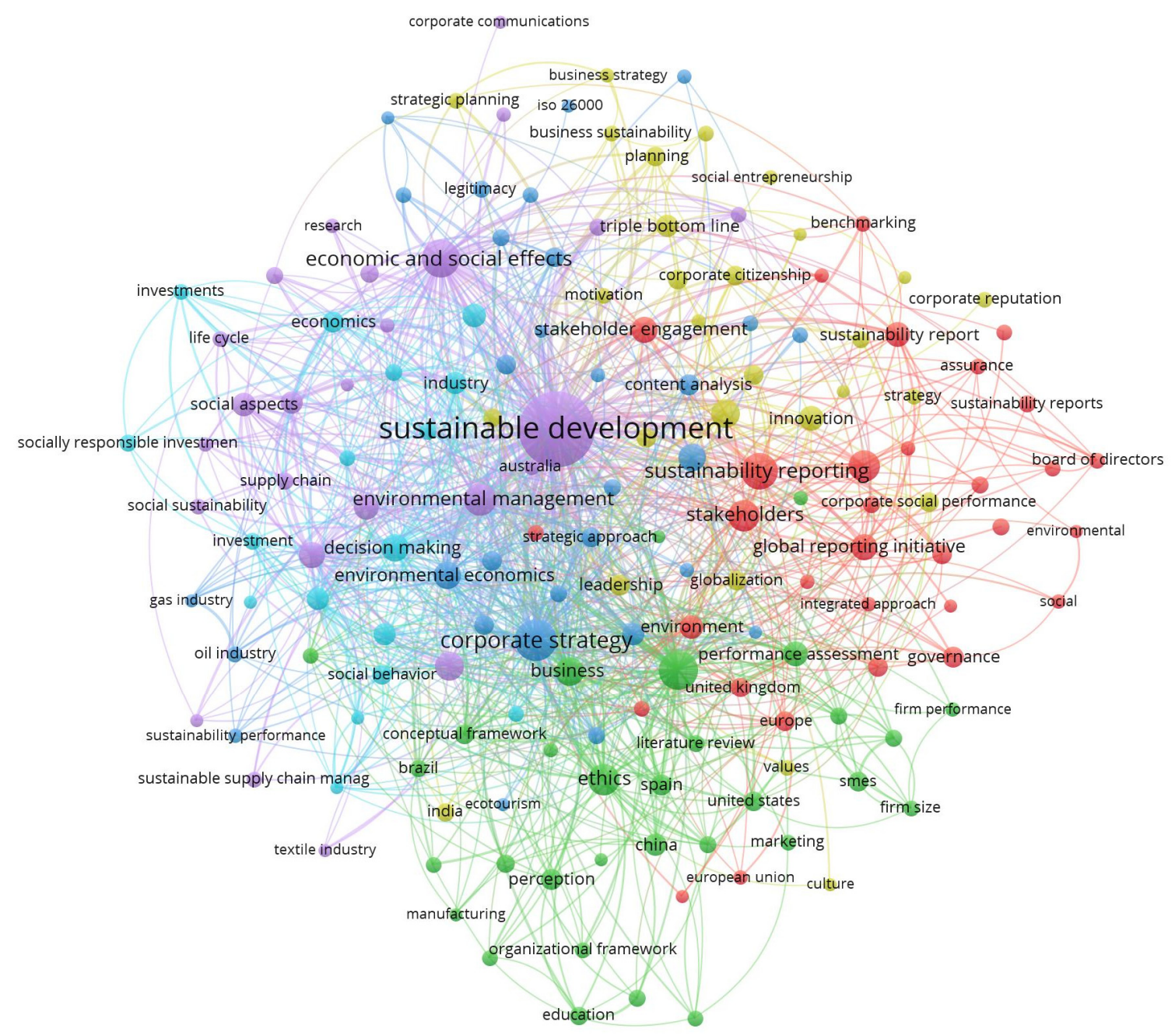

Figure 5. Keywords network based on co-occurrence from 2001 to 2018. 
As an added bonus, research on this topic continues to advance globally with other concepts and strategies, such as Corporate Sustainability, Environmental Economics, or Sustainable Supply Chain Management. It is also noteworthy that the 2014-2016 triennium analyzed illustrated a shift in research trends now aimed at evaluating CSR's sustainable approach according to the size of the company and analyzing the functions of the board in relation to CSR and sustainability. Organizations are also making an effort in line with education for sustainable development since it is understood that, as UNESCO points out, education, in all its forms and all its levels, is one of the most effective tools for inducing necessary changes in order to achieve sustainable development.

\section{Conclusions}

The goal of this study was to analyze research trends on corporate social responsibility practices focused on global sustainability over the past 18 years. A bibliometric analysis of 1832 articles obtained from the Scopus database has been developed. Thematic areas, journals, authors, institutions and countries have been identified in the most productive publications on CSR and sustainability. The number of scientific papers per year during the period 2001-2018 has increased, especially in the last six years where 760 articles have been published, representing $41.5 \%$ of contributions on this research topic. The thematic area Business, Management, and Accounting is the most notable since it groups $31 \%$ of the articles, followed by Social Sciences with $21 \%$, and Environmental Science with $14-\%$.

The most productive journals on CSR's sustainability approach research topic have been the Journal of Business Ethics and Sustainability with $6.1 \%$ of the total articles published each (111) in the analyzed period. It should be noted that $55 \%$ of the journals that contribute to this topic are positioned in Scopus' first quartile. Journal of Business Ethics is also the journal with the highest number of citations (4115), and the one with the highest $\mathrm{H}$ index for published articles on this subject area (42). The journal with the highest average number of citations per article is Business Horizons, with 49.22. Importantly, the journal Sustainability, although it had its first published article on the subject of study in 2013, has become the journal with the largest number of articles on CSR and sustainability in the last triennium, with 98 articles, which account for $27.8 \%$ of the total articles on this subject that have been published between 2016 and 2018, a fact that will be reflected in the citations of these works in the coming years.

The authors who have published the most on the link between CSR and sustainability are the Spaniards García-Sánchez (11 articles) and Moneva (8), and the Dutch Moratis (9). Kolk, from the University of Amsterdam, is the author with the highest number of citations (642) and the best average number of citations per article (107). The most prolific institutions in this area of research are the University of Salamanca (Spain) and the Wageningen University and Research Centre (Netherlands), with 22 and 18 articles, respectively. The Leuphana Universität Lüeneburg (Germany) has the highest number of quotations (716) and the best average number of quotations per item (47.73). Among the countries with the greatest number of institutions that have contributed to the subject of study is Spain with four.

The main countries that have made an effort in this area of research are, in order of importance: United States, United Kingdom, and Spain. The United States has the largest number of published articles (343) and citations (8482). As for the countries that have made greater international collaboration in their work, China and France have led the way.

This study has some limitations, which could be the basis for future research. Mainly, these come from the intrinsic characteristics of the quantitative analysis of the bibliometric method. One of these limitations is that some authors publish few articles with high influence in a certain field of research. In addition, this methodology could be extended with other databases or quantitative or qualitative tools, which would facilitate a different perspective of the study. On the other hand, other types of documents, in addition to scientific articles, could also be included in the search.

Future research lines on this topic will focus on CSR information in controversial industries, the development of sustainability-oriented capabilities for eco-innovation or ecological innovation, and 
the assessment of the impact of CSR sustainable growth. Contributions should also be made that study the impact of the supplier's sustainability risk on shareholder value and on the effect of the composition of an organization's Board of Directors in the actions on Sustainability. In addition, new studies need to interpret the CSR's challenge against the so-called Industry 4.0 in Europe, or Smart Industry, in the USA. Thus, this line must clarify theoretically and practically how social responsibility will respond to the trend towards the automation of industrial processes to optimize the organization and improve the competitiveness in the sector in which it is implanted. Various tools and technologies, such as the Internet of Things, Artificial Intelligence, Big Data, and Big Data Analytics, come into play in this new paradigm. Consequently, this is a new challenge for CSR and its involvement in this reality must be the subject of study.

Finally, it should be noted that trends in research on the sustainable approach of CSR globally have followed an upward trend and stabilized in optimal publication rates in recent years.

Author Contributions: This article is a joint work of the three authors. E.A.-S., L.J.B.-U. and F.J.C.-G. Conceptualization, methodology, software, validation, formal analysis, investigation, resources, E.A.-S. and L.J.B.-U. writing-review and editing, visualization, supervision, E.A.-S., L.J.B.-U. and F.J.C.-G. Project administration, funding acquisition, L.J.B.-U. and F.J.C.-G. All authors have written, reviewed and edited the manuscript, and have read and approved the final manuscript.

Funding: This research received no external funding.

Conflicts of Interest: The authors declare no conflict of interest.

\section{References}

1. Málovics, G.; Csigéné, N.N.; Kraus, S. The role of corporate social responsibility in strong sustainability. J. Socio Econ. 2008, 37, 907-918. [CrossRef]

2. Perez-Batres, L.A.; Miller, V.V.; Pisani, M.J. CSR, sustainability and the meaning of global reporting for Latin American corporations. J. Bus. Ethics 2010, 91, 193-209. [CrossRef]

3. Skaerseth, J.B.; Wettestad, J. A framework for assessing the sustainability impact of CSR. In Corporate Social Responsibility in Europe: Rhetoric and Realities; Regine Barth, R., Wolff, F., Eds.; Edward Elgar Publishing: Cheltenham Glos, UK, 2009; pp. 26-37. [CrossRef]

4. Ruggiero, P.; Cupertino, S. CSR strategic approach, financial resources and corporate social performance: The mediating effect of innovation. Sustainability 2018, 10, 3611. [CrossRef]

5. Kim, M.; Kim, B.; Oh, S. Relational benefit on satisfaction and durability in strategic corporate social responsibility. Sustainability 2018, 10, 1104. [CrossRef]

6. Ait Sidhoum, A.; Serra, T. Corporate sustainable development. Revisiting the relationship between corporate social responsibility dimensions. Sustain. Dev. 2018, 26, 365-378. [CrossRef]

7. Marco-Fondevila, M.; Moneva Abadía, J.M.; Scarpellini, S. CSR and green economy: Determinants and correlation of firms' sustainable development. Corp. Soc. Responsib. Environ. Manag. 2018, 25, 756-771. [CrossRef]

8. Buhr, N.; Gray, R.; Milne, M.J. Histories, rationales, voluntary standards and future prospects for sustainability reporting: CSR, GRI, IIRC and beyond. In Sustainability Accounting and Accountability; Routledge: London, UK, 2014; pp. 69-89.

9. Ranängen, H.; Lindman, Å. Exploring corporate social responsibility practice versus stakeholder interests in Nordic mining. J. Clean. Prod. 2018, 197, 668-677. [CrossRef]

10. Shabana, K.M.; Buchholtz, A.K.; Carroll, A.B. The institutionalization of corporate social responsibility reporting. Bus. Soc. 2017, 56, 1107-1135. [CrossRef]

11. Sachs, J.D.; Schmidt-Traub, G. Global fund lessons for sustainable development goals. Science 2017, 356, 32-33. [CrossRef]

12. Comisión Europea. Responsabilidad Social de las Empresas (RSE). Actividades de la UE y Nacionales Para Promover la RSE, Mejorar las Normas Medioambientales en las Empresas. Available online: https://ec. europa.eu/info/business-economy-euro/doing-business-eu/corporate-social-responsibility-csr_es (accessed on 21 September 2019). 
13. Compromiso RSE Custommedia. 7 Claves Para Entender la Nueva Directiva Europea Sobre Reporting en RSE. Available online: https://www.compromisorse.com/rse/2016/09/29/7-claves-para-entender-la-nuevadirectiva-europea-sobre-reporting-en-rse/ (accessed on 20 September 2019).

14. Forética. Avanzando Hacia un Nuevo Marco Regulatorio de Transparencia Estudio Sobre la Adaptación de la Directiva de Divulgación de Información no Financiera y Diversidad (2014/95/EU). Available online: https://www.foretica.org/Avanzando_hacia_un_nuevo_marco_regulatorio_de_transparencia_FORETICA_ BANKIA.pdf (accessed on 19 September 2019).

15. International Organization for Standardization. ISO 26000 Responsabilidad Social. Available online: https://www.iso.org/files/live/sites/isoorg/files/archive/pdf/en/iso_26000_project_overview-es.pdf (accessed on 20 September 2019).

16. Bowen, H.R. Social Responsibilities of the Businessman; University of Iowa Press: Ajova Siti, IA, USA, 2013. [CrossRef]

17. Carroll, A.B. The pyramid of corporate social responsibility: Toward the moral management of organizational stakeholders. Bus. Horiz. 1991, 34, 39-48. [CrossRef]

18. WCED. World Commission on Environment and Development: Our Common Future; Oxford University Press: Oxford, UK, 1987. Available online: https://idl-bnc-idrc.dspacedirect.org/bitstream/handle/10625/152/ WCED_v17_doc149.pdf?sequence (accessed on 22 August 2019).

19. Goel, P. Triple bottom line reporting: An analytical approach for corporate sustainability. J. Financ. Account. Manag. 2010, 1, 27-42.

20. Elkington, J. Partnerships from cannibals with forks: The triple bottom line of 21st-century business. Environ. Qual. Manag. 1998, 8, 37-51. [CrossRef]

21. Elkington, J. Enter the triple bottom line. In The Triple Bottom Line; Routledge: London, UK, 2013; pp. $23-38$.

22. Henriques, A. CSR, sustainability and the triple bottom line. In The Triple Bottom Line; Routledge: London, UK, 2013; pp. 48-55.

23. Alhaddi, H. Triple bottom line and sustainability: A literature review. Bus. Manag. Stud. 2015, 1, 6-10. [CrossRef]

24. Slaper, T.F.; Hall, T.J. The triple bottom line: What is it and how does it work. Indiana Bus. Rev. 2011, 86, 4-8.

25. Stenzel, P.L. Sustainability, the triple bottom line, and the global reporting initiative. Glob. Edge Bus. Rev. 2010, 4, 1-2.

26. UN Agenda 2030. Transforming Our World: The 2030 Agenda for Sustainable Development. 2015. Available online: https://sustainabledevelopment.un.org/post2015/transformingourworld (accessed on 22 August 2019).

27. De Paula, N. The agenda 2030 for responsible management education: An applied methodology. Int. J. Manag. Rev. Ed. 2017, 15, 183-191. [CrossRef]

28. Strezov, V.; Evans, A.; Evans, T.J. Assessment of the economic, social and environmental dimensions of the indicators for sustainable development. Sustain. Dev. 2017, 25, 242-253. [CrossRef]

29. Li, H.; Zhang, X.; Zhang, X.; Wu, Y. Utilization benefit of cultivated land and land institution reforms: Economy, society and ecology. Habitat Int. 2018, 77, 64-70. [CrossRef]

30. Khan, S.A.R.; Zhang, Y.; Anees, M.; Golpîra, H.; Lahmar, A.; Qianli, D. Green supply chain management, economic growth and environment: A GMM based evidence. J. Clean. Prod. 2018, 185, 588-599. [CrossRef]

31. Acheampong, A.O. Economic growth, $\mathrm{CO} 2$ emissions and energy consumption: What causes what and where? Energy Econ. 2018, 74, 677-692. [CrossRef]

32. Glavič, P.; Lukman, R. Review of sustainability terms and their definitions. J. Clean. Prod. 2007, 15, 1875-1885. [CrossRef]

33. Hahn, R.; Kühnen, M. Determinants of sustainability reporting: A review of results, trends, theory, and opportunities in an expanding field of research. J. Clean. Prod. 2013, 59, 5-21. [CrossRef]

34. Tilbury, D.; Ryan, A. Today becomes tomorrow: Re-thinking business practice, education and learning in the context of sustainability. J. Glob. Responsib. 2011, 2, 137-150. [CrossRef]

35. Hahn, T.; Figge, F.; Pinkse, J.; Preuss, L. A paradox perspective on corporate sustainability: Descriptive, instrumental, and normative aspects. J. Bus. Ethics 2018, 148, 235-248. [CrossRef]

36. Nikolaou, I.E.; Tsalis, T.A.; Evangelinos, K.I. A framework to measure corporate sustainability performance: A strong sustainability-based view of firm. Sustain. Prod. Consum. 2019, 18, 1-18. [CrossRef] 
37. Joshi, S.; Li, Y. What is corporate sustainability and how do firms practice it? A management accounting research perspective. J. Manag. Account. Res. 2016, 28, 1-11. [CrossRef]

38. Ashrafi, M.; Acciaro, M.; Walker, T.R.; Magnan, G.M.; Adams, M. Corporate sustainability in Canadian and US maritime ports. J. Clean. Prod. 2019, 220, 386-397. [CrossRef]

39. Baumgartner, R.J.; Rauter, R. Strategic perspectives of corporate sustainability management to develop a sustainable organization. J. Clean. Prod. 2017, 140, 81-92. [CrossRef]

40. Ivory, S.B.; Brooks, S.B. Managing corporate sustainability with a paradoxical lens: Lessons from strategic agility. J. Bus. Ethics 2018, 148, 347-361. [CrossRef]

41. Grewatsch, S.; Kleindienst, I. How organizational cognitive frames affect organizational capabilities: The context of corporate sustainability. Long Range Plan. 2018, 51, 607-624. [CrossRef]

42. Silvestre, W.J.; Antunes, P.; Leal Filho, W. The corporate sustainability typology: Analysing sustainability drivers and fostering sustainability at enterprises. Technol. Econ. Dev. Econ. 2018, 24, 513-533. [CrossRef]

43. Kang, J.S.; Chiang, C.F.; Huangthanapan, K.; Downing, S. Corporate social responsibility and sustainability balanced scorecard: The case study of family-owned hotels. Int. J. Hosp. Manag. 2015, 48, 124-134. [CrossRef]

44. Kolk, A. The social responsibility of international business: From ethics and the environment to CSR and sustainable development. J. World Bus. 2016, 51, 23-34. [CrossRef]

45. Freeman, R.E. The Politics of Stakeholder Theory: Some Future Directions. Bus. Ethics Q. 1994, 4, 409-421. [CrossRef]

46. Roberts, R.W. Determinants of corporate social responsibility disclosure: An application of stakeholder theory. Account. Organ. Soc. 1992, 17, 595-612. [CrossRef]

47. Carson, T.L. Does the stakeholder theory constitute a new kind of theory of social responsibility? Bus. Ethics Q. 1993, 3, 171-176. [CrossRef]

48. McWilliams, A.; Siegel, D. Corporate social responsibility: A theory of the firm perspective. Acad. Manag. Rev. 2001, 26, 117-127. [CrossRef]

49. Phillips, R.; Freeman, R.E.; Wicks, A.C. What stakeholder theory is not. Bus. Ethics Q. 2003, 13, 479-502. [CrossRef]

50. Campbell, J.L. Why would corporations behave in socially responsible ways? An institutional theory of corporate social responsibility. Acad. Manag. Rev. 2007, 32, 946-967. [CrossRef]

51. Carroll, A.B.; Shabana, K.M. The business case for corporate social responsibility: A review of concepts, research and practice. Int. J. Manag. Rev. 2010, 12, 85-105. [CrossRef]

52. O'Riordan, L.; Fairbrass, J. Managing CSR stakeholder engagement: A new conceptual framework. J. Bus. Ethics 2014, 125, 121-145. [CrossRef]

53. Witkowska, J. Corporate social responsibility: Selected theoretical and empirical aspects. Comp. Econ. Res. 2016, 19, 27-43. [CrossRef]

54. Ross, D. A research-informed model for corporate social responsibility: Towards accountability to impacted stakeholders. Int. J. Corp. Soc. Responsib. 2017, 2. [CrossRef]

55. Carson, T. Friedman's theory of corporate social responsibility. Bus. Prof. Ethics J. 1993, 12, 3-32. [CrossRef]

56. Tse, T. Shareholder and stakeholder theory: After the financial crisis. Qual. Res. Financ. Mark. 2011, 3, 51-63. [CrossRef]

57. Windsor, D. Corporate social responsibility and irresponsibility: A positive theory approach. J. Bus. Res. 2013, 66, 1937-1944. [CrossRef]

58. Ferrero, I.; Michael Hoffman, W.; McNulty, R.E. Must Milton Friedman embrace stakeholder theory? Bus. Soc. Rev. 2014, 119, 37-59. [CrossRef]

59. Porter, M.E.; Kramer, M.R. Creating value shared. Harv. Bus. Rev. 2011, 89, 62-77.

60. Guthrie, J.; Parker, L.D. Corporate social reporting: A rebuttal of legitimacy theory. Account. Bus. Res. 1989, 19, 343-352. [CrossRef]

61. Wilmshurst, T.D.; Frost, G.R. Corporate environmental reporting: A test of legitimacy theory. Account. Audit. Account. J. 2000, 13, 10-26. [CrossRef]

62. Filatotchev, I.; Nakajima, C. Corporate governance, responsible managerial behavior, and corporate social responsibility: Organizational efficiency versus organizational legitimacy? Acad. Manag. Perspect. 2014, 28, 289-306. [CrossRef]

63. Frynas, J.G.; Yamahaki, C. Corporate social responsibility: Review and roadmap of theoretical perspectives. Bus. Ethics A Eur. Rev. 2016, 25, 258-285. [CrossRef] 
64. Wilburn, K.; Wilburn, R. Achieving social lisence to operate using stakeholder theory. J. Int. Bus. Ethics 2011, 4, 3-16.

65. Devine, C.T. Research methodology and accounting theory formation. Account. Rev. 1960, 35, 387.

66. Cooper, D.J.; Sherer, M.J. The value of corporate accounting reports: Arguments for a political economy of accounting. Account. Organ. Soc. 1984, 9, 207-232. [CrossRef]

67. Malmi, T.; Granlund, M. In search of management accounting theory. Eur. Account. Rev. 2009, 18, 597-620. [CrossRef]

68. De Roover, R. The concept of the just price: Theory and economic policy. J. Econ. Hist. 1958, 18, 418-434. [CrossRef]

69. McNulty, P.J. Economic theory and the meaning of competition. Q. J. Econ. 1968, 82, 639-656. [CrossRef]

70. Steinberg, R. Economic theories of nonprofit organizations. In The Study of the Nonprofit Enterprise; Springer: Boston, MA, USA, 2003; pp. 277-309.

71. Scott, W.R. Institutional theory: Contributing to a theoretical research program. Great Minds Manag. Process Theory Dev. 2005, 37, 460-484.

72. Kostova, T.; Roth, K.; Dacin, M.T. Institutional theory in the study of multinational corporations: A critique and new directions. Acad. Manag. Rev. 2008, 33, 994-1006. [CrossRef]

73. Suddaby, R. Challenges for institutional theory. J. Manag. Inq. 2010, 19, 14-20. [CrossRef]

74. Brammer, S.; Jackson, G.; Matten, D. Corporate social responsibility and institutional theory: New perspectives on private governance. Socio Econ. Rev. 2012, 10, 3-28. [CrossRef]

75. Salancik, G.R.; Pfeffer, J. The bases and use of power in organizational decision making: The case of a university. Adm. Sci. Q. 1974, 19, 453-473. [CrossRef]

76. Salancik, G.R.; Pfeffer, J. Who gets power-And how they hold on to it: A strategic-contingency model of power. Organ. Dyn. 1977, 5, 3-21. [CrossRef]

77. Stone, E.F. Misperceiving and/or misrepresenting the facts: A reply to Salancik. J. Manag. 1984, 10, $255-258$. [CrossRef]

78. Finkelstein, S. Interindustry merger patterns and resource dependence: A replication and extension of Pfeffer. Strateg. Manag. J. 1997, 18, 787-810. [CrossRef]

79. Nienhüser, W. Resource dependence theory: How well does it explain behavior of organizations? Manag. Rev. 2008, 19, 9-32. [CrossRef]

80. Hillman, A.J.; Withers, M.C.; Collins, B.J. Resource dependence theory: A review. J. Manag. 2009, 35, 1404-1427. [CrossRef]

81. Hessels, J.; Terjesen, S. Resource dependency and institutional theory perspectives on direct and indirect export choices. Small Bus. Econ. 2010, 34, 203-220. [CrossRef]

82. Hofer, C.; Jin, H.; Swanson, R.D.; Waller, M.A.; Williams, B.D. The impact of key retail accounts on supplier performance: A collaborative perspective of resource dependency theory. J. Retail. 2012, 88, 412-420. [CrossRef]

83. Daly, H.E. Sustainable development: From concept and theory to operational principles. Popul. Dev. Rev. 1990, 16, 25-43. [CrossRef]

84. Garriga, E.; Melé, D. Corporate social responsibility theories: Mapping the territory. J. Bus. Ethics 2004, 53, 51-71. [CrossRef]

85. Jamali, D.; Mirshak, R. Corporate social responsibility (CSR): Theory and practice in a developing country context. J. Bus. Ethics 2007, 72, 243-262. [CrossRef]

86. Aguilera, R.V.; Rupp, D.E.; Williams, C.A.; Ganapathi, J. Putting the S back in corporate social responsibility: A multilevel theory of social change in organizations. Acad. Manag. Rev. 2007, 32, 836-863. [CrossRef]

87. Hacking, T.; Guthrie, P. A framework for clarifying the meaning of triple bottom-line, integrated, and sustainability assessment. Environ. Impact Assess. Rev. 2008, 28, 73-89. [CrossRef]

88. Anand Kumar, D.; Balakrishnan, V. Corporate social responsibility: Existing practices vs CSR framework. Glob. J. Manag. Bus. Res. 2011, 11, 51-56.

89. McWilliams, A.; Siegel, D.S. Creating and capturing value: Strategic corporate social responsibility, resource-based theory, and sustainable competitive advantage. J. Manag. 2011, 37, 1480-1495. [CrossRef]

90. Gibson, K. Stakeholders and sustainability: An evolving theory. J. Bus. Ethics 2012, 109, 15-25. [CrossRef] 
91. Baumgartner, R.J. Managing corporate sustainability and CSR: A conceptual framework combining values, strategies and instruments contributing to sustainable development. Corp. Soc. Responsib. Environ. Manag. 2014, 21, 258-271. [CrossRef]

92. Emas, R. The Concept of Sustainable Development: Definition and Defining Principles. Brief for GSDR 2015. pp. 1-3. Available online: https://sustainabledevelopment.un.org/content/documents/5839GSDR\%202015_ SD_concept_definiton_rev.pdf. (accessed on 22 August 2019).

93. Büchner, L.M. Corporate social responsibility and sustainability from a global, european and corporate perspective. Corporate social responsibility and sustainable G. Eurolimes 2012, 13, 41-55.

94. Cherapanukorn, V.; Focken, K. Corporate social responsibility (CSR) and sustainability in Asian luxury hotels: Policies, practices and standards. Asian Soc. Sci. 2014, 10, 198. [CrossRef]

95. Jain, R.; Winner, L.H. CSR and sustainability reporting practices of top companies in India. Corp. Commun. Int. J. 2016, 21, 36-55. [CrossRef]

96. Karcagi-Kovats, A. Performance indicators in CSR and sustainability reports in Hungary. Apstract Appl. Stud. Agribus. Commer. 2012, 6, 137-142. [CrossRef]

97. Orlitzky, M.; Siegel, D.S.; Waldman, D.A. Strategic corporate social responsibility and environmental sustainability. Bus. Soc. 2011, 50, 6-27. [CrossRef]

98. Sarvaiya, H.; Wu, M. An integrated approach for corporate social responsibility and corporate sustainability. Asian Soc. Sci. 2014, 10, 57. [CrossRef]

99. Arrive, T.J.; Feng, M.; Yan, Y.; Chege, S.M. The involvement of telecommunication industry in the road to corporate sustainability and corporate social responsibility commitment. Corp. Soc. Responsib. Environ. Manag. 2019, 26, 152-158. [CrossRef]

100. Kim, S.; Ji, Y. Chinese consumers' expectations of corporate communication on CSR and sustainability. Corp. Soc. Responsib. Environ. Manag. 2017, 24, 570-588. [CrossRef]

101. Grosser, K. Corporate social responsibility and gender equality: Women as stakeholders and the European Union sustainability strategy. Bus. Ethics A Eur. Rev. 2009, 18, 290-307. [CrossRef]

102. Grosser, K.; Moon, J. CSR and feminist organization studies: Towards an integrated theorization for the analysis of gender issues. J. Bus. Ethics 2019, 155, 321-342. [CrossRef]

103. Liao, P.C.; Xia, N.N.; Wu, C.L.; Zhang, X.L.; Yeh, J.L. Communicating the corporate social responsibility (CSR) of international contractors: Content analysis of CSR reporting. J. Clean. Prod. 2017, 156, 327-336. [CrossRef]

104. Du, S.; Bhattacharya, C.B.; Sen, S. Maximizing business returns to corporate social responsibility (CSR): The role of CSR communication. Int. J. Manag. Rev. 2010, 12, 8-19. [CrossRef]

105. Nor, S.M.; Hashim, N.A. CSR and sustainability of Islamic banking: The bankers view. J. Pengur. 2015, 45, 73-81.

106. Lockett, A.; Moon, J.; Visser, W. Corporate social responsibility in management research: Focus, nature, salience and sources of influence. J. Manag. Stud. 2006, 43, 115-136. [CrossRef]

107. Ratajczak, P.; Szutowski, D. Exploring the relationship between CSR and innovation. Sustain. Account. Manag. Policy J. 2016, 7, 295-318. [CrossRef]

108. Busch, T.; Bauer, R.; Orlitzky, M. Sustainable development and financial markets: Old paths and new avenues. Bus. Soc. 2016, 55, 303-329. [CrossRef]

109. Soderstrom, K.M.; Soderstrom, N.S.; Stewart, C.R. Sustainability/CSR research in management accounting: A review of the literature. In Advances in Management Accounting; Emerald Publishing Limited: Bradford, UK, 2017; pp. 59-85.

110. Landrum, N.E.; Ohsowski, B. Identifying worldviews on corporate sustainability: A content analysis of corporate sustainability reports. Bus. Strategy Environ. 2018, 27, 128-151. [CrossRef]

111. Aznar-Sánchez, J.A.; Belmonte-Ureña, L.J.; López-Serrano, M.J.; Velasco-Muñoz, J.F. Forest ecosystem services: An analysis of worldwide research. Forests 2018, 9, 453. [CrossRef]

112. Rodrigues, M.; Mendes, L. Mapping of the literature on social responsibility in the mining industry: A systematic literature review. J. Clean. Prod. 2018, 181, 88-101. [CrossRef]

113. Tiba, S.; van Rijnsoever, F.J.; Hekkert, M.P. Firms with benefits: A systematic review of responsible entrepreneurship and corporate social responsibility literature. Corp. Soc. Responsib. Environ. Manag. 2019, 26, 265-284. [CrossRef]

114. Illiashenko, S.; Peresadko, G. Corporate social responsibility in marketing researches: Literature review. Corp. Ownersh. Control. 2014, 11. [CrossRef] 
115. Glavas, A. Corporate social responsibility and organizational psychology: An integrative review. Front. Psychol. 2016, 7. [CrossRef]

116. Kudłak, R.; Low, K.Y. Special issues dedicated to CSR and corporate sustainability: A review and commentary. Long Range Plan. 2015, 48, 215-227. [CrossRef]

117. Molina-Moreno, V.; Leyva-Díaz, J.; Sánchez-Molina, J.; Peña-García, A. Proposal to foster sustainability through circular economy-based engineering: A profitable chain from waste management to tunnel lighting. Sustainability 2017, 9, 2229. [CrossRef]

118. Niehm, L.S.; Swinney, J.; Miller, N.J. Community social responsibility and its consequences for family business performance. J. Small Bus. Manag. 2008, 46, 331-350. [CrossRef]

119. Yazici, Ö.; Mcwilliams, D.; Ercan, S. CSR comparison between family businesses and non-family business. Business \& Management Studies: An International Journal. 2018, 6, 256-280. [CrossRef]

120. Zavaraqi, R.; Fadaie, G.R. Scientometrics or science of science: Quantitative, qualitative or mixed one. Collnet J. Scientometr. Inf. Manag. 2012, 6, 273-278. [CrossRef]

121. Aznar-Sánchez, J.A.; Velasco-Muñoz, J.F.; Belmonte-Ureña, L.J.; Manzano-Agugliaro, F. Innovation and technology for sustainable mining activity: A worldwide research assessment. J. Clean. Prod. 2019, 221, 38-54. [CrossRef]

122. Van Eck, N.J.; Waltman, L. Visualizing bibliometric networks. In Measuring Scholarly Impact: Methods and Practice; Ding, Y., Rousseau, R., Wolfram, D., Eds.; Springer International Publishing: Cham, Switzerland, 2014; pp. 285-320.

123. Aznar-Sánchez, J.A.; Velasco-Muñoz, J.F.; Belmonte-Ureña, L.J.; Manzano-Agugliaro, F. The worldwide research trends on water ecosystem services. Ecol. Indic. 2019, 99, 310-323. [CrossRef]

124. Yu, C.; Davis, C.; Dijkema, G.P. Understanding the evolution of industrial symbiosis research: A bibliometric and network analysis (1997-2012). J. Ind. Ecol. 2014, 18, 280-293. [CrossRef]

125. Núñez-Cacho, P.; Gorecki, J.; Molina, V.B.; Corpas-Iglesias, F.A. New Measures of Circular Economy Thinking in Construction Companies. Journal of EU Research in Business 2018, 16. [CrossRef]

126. Klopotan, I.; Zoroja, J.; Meško, M. Early warning system in business, finance, and economics: Bibliometric and topic analysis. Int. J. Eng. Bus. Manag. 2018, 10. [CrossRef]

127. Martins-Rodrigues, M.C.; Camargo, C.R.; Barbieri, L.C.; Gomes, C.M. Tourism and corporate responsibility: A bibliometric study of the scientific production in the Web of Science and Scopus in the period 2007 to 2017. Tour. Hosp. Int. J. 2019, 12, 164-190.

128. Hallinger, P.; Chatpinyakoop, C. A bibliometric review of research on higher education for sustainable development, 1998-2018. Sustainability 2019, 11, 2401. [CrossRef]

129. Honoré, M.N.; Belmonte-Ureña, L.J.; Navarro-Velasco, A.; Camacho-Ferre, F. Profit analysis of papaya crops under greenhouses as an alternative to traditional intensive horticulture in southeast Spain. Int. J. Environ. Res. Public Health 2019, 16, 2908. [CrossRef] [PubMed]

130. Neff, M.W.; Corley, E.A. 35 years and 160,000 articles: A bibliometric exploration of the evolution of ecology. Scientometrics 2009, 80, 657-682. [CrossRef]

131. Palomo, J.; Figueroa-Domecq, C.; Laguna, P. Women, peace and security state-of-art: A bibliometric analysis in social sciences based on SCOPUS database. Scientometrics 2017, 113, 123-148. [CrossRef]

132. Sanguankaew, P.; Vathanophas Ractham, V. Bibliometric review of research on knowledge management and sustainability, 1994-2018. Sustainability 2019, 11, 4388. [CrossRef]

133. Mao, G.; Liu, X.; Du, H.; Zuo, J.; Wang, L. Way forward for alternative energy research: A bibliometric analysis during 1994-2013. Renew. Sust. Energ. Rev. 2015, 48, 276-286. [CrossRef]

134. Durieux, V.; Gevenois, P.A. Bibliometric indicators: Quality measurements of scientific publication 1. Radiology 2010, 255, 342-351. [CrossRef]

135. Van Eck, N.J.; Waltman, L. Software survey: VOSviewer, a computer program for bibliometric mapping. Scientometrics 2010, 84, 523-538. [CrossRef]

136. Courtial, J. A coword analysis of scientometrics. Scientometrics 1994, 31, 251-260. [CrossRef]

137. Ravikumar, S.; Agrahari, A.; Singh, S.N. Mapping the intellectual structure of scientometrics: A co-word analysis of the journal Scientometrics (2005-2010). Scientometrics 2015, 102, 929-955. [CrossRef]

138. Vellino, A. Recommending research articles using citation data. Libr. Hi Tech. 2015, 33, 597-609. [CrossRef]

139. Craig, I.D.; Plume, A.M.; McVeigh, M.E.; Pringle, J.; Amin, M. Do open access articles have greater citation impact? A critical review of the literature. J. Informetr. 2007, 1, 239-248. [CrossRef] 
140. Plaza-Ubeda, J.A.; De Burgos-Jiménez, J.; Belmonte-Ureña, L.J. Stakeholders, environmental management and performance: An integrated approach. Cuad. Econ. Dir. Empresa 2011, 14, 151-161.

141. Cai, Y.; Jo, H.; Pan, C. Doing well while doing bad? CSR in controversial industry sectors. J. Bus. Ethics 2011, 108, 467-480. [CrossRef]

142. Gabler, C.B.; Richey, R.G.; Rapp, A. Developing an eco-capability through environmental orientation and organizational innovativeness. Ind. Mark. Manag. 2015, 45, 151-161. [CrossRef]

143. Almeida Souza, A.A.; Rodrigues Alves, M.F.; Macini, N.; Oranges Cezarino, L.; Bartocci Liboni, L. Resilience for sustainability as an eco-capability. Int. J. Clim. Chang. Strateg. Manag. 2017, 9, 581-599. [CrossRef]

144. Nicolăescu, E.; Alpopi, C.; Zaharia, C. Measuring Corporate Sustainability Performance. Sustainability 2015, 7, 851-865. [CrossRef]

145. Kim, W.; Khan, G.; Wood, J.; Mahmood, M. Employee engagement for sustainable organizations: Keyword analysis using social network analysis and burst detection approach. Sustainability 2016, 8, 631. [CrossRef]

146. Halme, M.; Rintamäki, J.; Knudsen, J.S.; Lankoski, L.; Kuisma, M. When is there a sustainability case for CSR? Pathways to environmental and social performance improvements. Bus. Soc. 2018, 000765031875564. [CrossRef]

147. Mebratu, D. Sustainability and sustainable development: Historical and conceptual review. Environ. Impact Assess. Rev. 1998, 18, 493-520. [CrossRef]

148. Cloutier, S.; Pfeiffer, D. Sustainability through happiness: A framework for sustainable development. Sustain. Dev. 2015, 23, 317-327. [CrossRef]

149. Scherer, A.G.; Palazzo, G.; Seidl, D. Managing legitimacy in complex and heterogeneous environments: Sustainable development in a globalized world. J. Manag. Stud. 2013, 50, 259-284. [CrossRef]

150. Hall, J.; Vredenburg, H. The challenge of innovating for sustainable development. Mit Sloan Manag. Rev. 2003, 45, 61 .

(C) 2019 by the authors. Licensee MDPI, Basel, Switzerland. This article is an open access article distributed under the terms and conditions of the Creative Commons Attribution (CC BY) license (http://creativecommons.org/licenses/by/4.0/). 